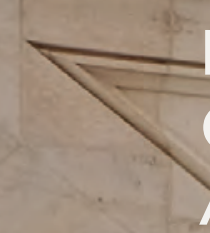

LISBOA, TURIM E O INTERCÂMBIO

CULTURAL DO SÉCULO DAS LUZES

ȦEUROPA PÓS-NAPOLEÓNICA

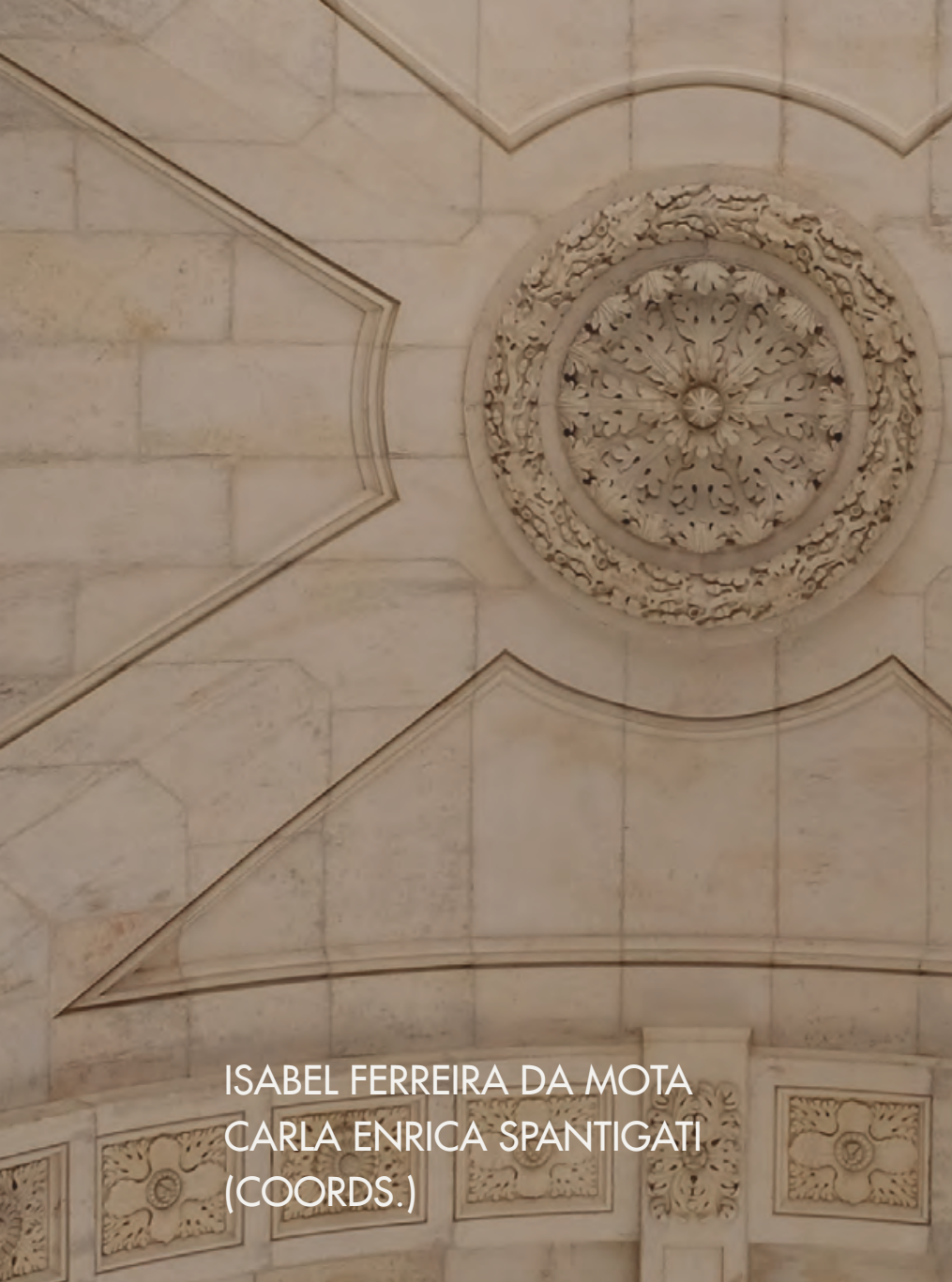

IMPRENSA DA

UNIVERSIDADE DE COIMBRA COIMBRA UNIVERSITY PRESS

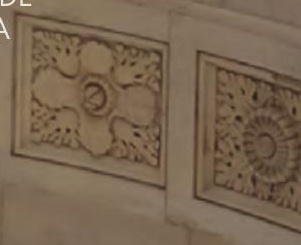


Assente numa abordagem interdisciplinar, este volume fornece uma perspectiva-plurifacetada sobre um período particularmente importante da constituição e recomposição da geografia artístico-cultural e política europeia, na transição do sécullo XVIII para o século XIX. Elege como foco de análise as relações entre Lisboa e Turim e a sua exemplaridade no âmbito das formas de sociabilidade e circulação de objectos, saberes, gostos, estilos de governo e políticas públicas, sobre as quais se construiu o panorama geopolítico europeu e mesmo a sua projecção nos impérios. Sendo múltiplas as abordagens ao tema em apreço, - que as une é uma concepção alargada de cultura e história cultural, que vai da cultura-visual à cultura científica, da cultura material à cultura política. As ligaçóes estabelecem-se na infraestrutura das sensibilidades e na transferência dos gostos e dos habitus. 


\section{EDIÇÃo}

Imprensa da Universidade de Coimbra Email: imprensa@uc.pt

URL: http//www.uc.pt/imprensa_uc

Vendas online: http://livrariadaimprensa.uc.pt

COORDENAÇÃo EDITORIAL

Imprensa da Universidade de Coimbra

CONCEÇÃo GRÁFICA

Imprensa da Universidade de Coimbra

IMAGEM DA CAPA

Julien Chatelain from Paris, France [CC BY-SA 2.0

(https://creativecommons.org/licenses/by-sa/2.0)]

\section{INFOGRAFIA}

Bookpaper

EXECUÇÃo GRÁFICA

Simões e Linhares, Lda.

ISBN

978-989-26-1738-1

ISBN DIGITAL

978-989-26-1739-8

DOI

https://doi.org/10.14195/978-989-26-1739-8

DEPÓSITO LEGAL

460666/19

C SETEMBRO 2019, IMPRENSA DA UNIVERSIDADE DE COIMBRA

Tanto ella assume novitate al fianco / coord.

Isabel Ferreira da Mota, Carla Enrica Spantigati.

- (Investigação)

ISBN 978-989-26-1738-1 (ed. impressa)

ISBN 978-989-26-1739-8 (ed. eletrónica)

I - MOTA, Isabel Ferreira da, 1963-

II - SPANTIGATI, Carla Enrica

CDU 94(469)"17"(042) 
TANTO ELLA ASSUME NOVITATE AL FIANCO

LISBOA, TURIM E O INTERCÂMBIO CULTURAL DO SÉCULO DAS LUZES À EUROPA PÓS-NAPOLEÓNICA

ISABEL FERREIRA DA MOTA CARLA ENRICA SPANTIGATI (COORDS.)
IMPRENSA DA

UNIVERSIDADE DE COIMBRA

COIMBRA

UNIVERSITY

PRESS 
(Página deixada propositadamente em branco) 


\section{S U M Á R I O}

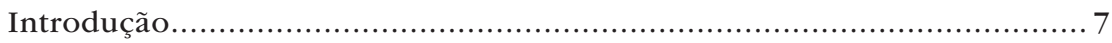

Isabel Ferreira da Mota e Carla Enrica Spantigati

D. Rodrigo de Sousa Coutinho em Turim: cultura económica

e formação política de um diplomata ilustrado .

José Luís Cardoso

Turim-Lisboa 1769-1796. O olhar dos embaixadores

49

Gian Paolo Romagnani

Da viagem à Itália à prática institucional e política:

entre Turim e Lisboa

Isabel Ferreira da Mota

Ciência, Diplomacia e Viagem: Dom Rodrigo de Souza Coutinho

e o tour mineralógico dos savants luso-brasileiros José Bonifácio

de Andrada e Silva e Manoel Ferreira da Câmara Bithencourt

em Turim...

Junia Ferreira Furtado

Vincenzo Belli (1710-1787). Percurso de um ourives: um turinês em Roma que trabalhou para Lisboa

Teresa Leonor M. Vale 
De Lisboa a Turim. Porcelanas e "casse di vernice della Cina» para o ministro plenipotenciário Carlo Francesco II Valperga di Masino

Cristina Mossetti, Lucia Caterina, Sabrina Beltramo, Laura Tos, Corrado Trione

Giuseppe Trono em Portugal: Um pinto de retratos piemontês entre monarquia e revolução (1785-1810).

Giuseppina Raggi, Michela Degortes

A arte na mala diplomática

Carla Enrica Spantigati

Luigi Cinatti e os "ammodernamenti" de Palagi nas residências da Casa de Saboia

Monica Tomiato

Fontes e documentos sobre as relações musicais entre Turim

e Lisboa na segunda metade do século XVIII 359

Annarita Colturato

Il furioso nell'Isola di San Domingo de Donizetti: o percurso de uma opera semisseria na época romântica entre Itália e Portugal.... 393 Luísa Cymbron

Lista onomástica. 421 


\title{
GIUSEPPE TRONO EM PORTUGAL: UM PINTOR DE RETRATOS PIEMONTÊS ENTRE MONARQUIA E REVOLUÇÃO $(1785-1810)^{1}$
}

\author{
Giuseppina Raggi (CES - UC) \\ e Michela Degortes (ARTIS - UL)
}

A leitura da correspondência diplomática permitiu reconstruir os acontecimentos que levaram Giuseppe Trono (Turim, 1739-Lisboa, 1810) a Lisboa em março de 1785 , e esclareceu os motivos que estiveram na base da sua escolha como retratista da corte portuguesa. Além do seu papel político e institucional, os diplomatas foram importantes mediadores culturais que deram um grande impulso à difusão das ideias através do envio de livros, jornais e impressos relativos à produção científica, literária, musical e artística; favoreceram também a migração dos artistas, por vezes determinando o seu êxito

\footnotetext{
${ }^{1}$ Pela valiosa ajuda que recebemos ao longo da investigação que está na origem deste ensaio queremos agradecer a: Alberto Seabra (Museu Nacional de Arte Antiga), Vitor Serrão (ARTIS, UL), Inês Ferro e Conceição Coelho (Palácio Nacional de Queluz), Mariana Bobone (Museu dos Coches), Paulo Almeida Fernandes (Museu da Cidade), Coronel Francisco Amado Rodrigues (Academia Militar - Palácio da Bemposta), Fátima Fernandes (Asilo de Inválidos Militares de Runa), Eva Lena Karlsson (Nacional Musem Stockholm), Diogo Mota (Academia das Ciências) Javier Jordán de Urrés (Palacio Real de Aranjuez), José Luís Sancho (Palacio Real de Madrid), Joaquina Feijão (Biblioteca Nacional de Lisboa), Maria Campilho Sousa Holstein e João Vinagre.
} 
nas respetivas cortes, o que aconteceu também no caso de Trono (que muitas vezes a bibliografia artística portuguesa chama Troni) ${ }^{2}$.

Pelo que diz respeito às trocas culturais entre a Itália e Portugal, no período que vai do fim do século XVIII aos primórdios do século XIX, a circulação de artistas e de obras de arte entre os dois países passa sobretudo por Roma, quer pelo indesmentível papel cultural que esta cidade desempenhava, quer pela importância das relações políticas com a Santa Sé, embora se deva ter em conta também a rede de contactos estabelecida com as principais cidades italianas de Nápoles, Turim e Génova.

Ao longo do século XVIII, o movimento de artistas, músicos e artesãos italianos que migram para Portugal é sem dúvida notável, mas durante o reinado de D. Maria I (1734-1816) assiste-se também ao fenómeno contrário: um ténue fluxo de artistas portugueses que se deslocam a Roma a fim de concluir a sua formação nos ateliers dos grandes mestres; um fenómeno que levará mais tarde, graças à iniciativa do ministro em missão na Santa Sé, Alexandre Sousa Holstein (1751-1803), à fundação de uma Academia Portuguesa de Belas Artes em Roma, "ressuscitando"3 um projeto de D. João V e contribuindo para reforçar as relações artísticas com a Itália. Neste sentido, é preciso sublinhar a inclinação da rainha para retomar, embora de forma mais contida, as políticas artísticas da época joanina, e para introduzir umas novidades de relevo no contexto cultural

2 A alteração do nome é frequente na literatura portuguesa. Cyrilo Volkmar Machado, autor da primeira biografia do pintor, chamou-o José Throno. MACHADO, C. Volkmar (1823), Coleção de memórias relativas ás vidas dos pintores, e escultores, architectos e gravadores portuguezes e dos estrangeiros que estiveram em Portugal, Na Imp. Vitorino Rodrigues da Silva, Lisboa, pp. 129-133

3 A expressão é de Sousa Holstein e refere-se à Academia de Belas Artes que D. João V mandou instituir em Roma em 1720 e que fechou cerca de dez anos mais tarde. Sobre a instituição fundada em 1791 por Sousa Holstein e dirigida por Giovanni Gherardo de Rossi veja-se DEGORTES, M. (2016), Ensino artístico no estrangeiro e relações internacionaes: o caso da Academia Portuguesa de Belas Artes em Roma, in M. J. Neto, M. Malta (edição de), Coleções de arte em Portugal e Brasil nos séculos XIX e XX, Caleidoscópio, Casal de Cambra, pp. 137-48. 
português4; também a decisão de contratar um "bom pintor" de retratos pode ser vista, em parte, no âmbito dessas iniciativas, se considerarmos que ao artista se pedia expressamente a criação de uma escola, una cláusula que reflete a preocupação com o problema do ensino artístico5.

A urgência em contratar um pintor retratista por volta de meados de 1784 está associada à necessidade de enfatizar a imagem da família real, tendo em vista os iminentes casamentos que reforçariam a aliança entre a dinastia de Bragança e a de Bourbon: o da infanta Carlota Joaquina de Bourbon (1775-1830), filha do príncipe Carlos IV de Espanha e o de Maria Luisa de Parma, com o infante D. João (1767-1826), ${ }^{6}$ filho da rainha D. Maria I e de D. Pedro III de Bragança, e também o casamento que o rei Carlos III de Espanha propôs entre o seu filho Gabriel de Bourbon (1752-1788) e Mariana Vitória de Bragança (1768-1788), terceira filha da rainha portuguesa. Os acordos matrimoniais, concluídos em 1783, seguem uma linha de ação que visa tornar mais sólida a aliança entre a Espanha e Portugal. A decisão de contratar um pintor retratista enquadra-se num contexto político fortemente comemorativo que, segundo uma modalidade bastante típica, previa a troca de retratos entre as cortes, quer durante os preparativos para os casamentos, quer numa fase sucessiva, e implicava o envio de miniaturas e de pinturas a óleo. Os dois retratos de corpo inteiro da jovem Carlota Joaquina conservados no Prado, e que foram pintados por Salvador Maella ${ }^{7}$ e por Giuseppe

\footnotetext{
${ }^{4}$ Lembramos, entre outras iniciativas, a fundação da Academia das Ciências, da Real Biblioteca Pública, do Museu de História Natural e da Real Casa Pia.

5 Lisboa, Arquivo Nacional da Torre do Tombo (ANTT), Ministério dos Negócios Estrangeiros (MNE) Cx. 830; rascunho do ministro Ayres de Sa Mello para Diogo da Noronha, datado de 29 de junho de 1784.

${ }^{6}$ Por causa da morte do irmão mais velho D. José, D. João tornou-se o novo príncipe herdeiro e subiu ao trono com o nome de D. João VI.

7 FlANDES, J. de, LOPEZ, A. (2015), El Retrato en las Colecciones Reales de Patrimonio Nacional, Patrimonio Nacional, Madrid.
} 
Trono, estão relacionados com essas circunstâncias, assim como os retratos das miniaturas em marfim de D. Maria I, do infante D. João e da infanta Carlota Joaquina ${ }^{8}$, executados pelo pintor piemontês.

\section{O contrato de retratista régio e a viagem para Lisboa: documentos inéditos}

A história do contrato de Trono desenrola-se paralelamente à das pinturas encomendadas a Pompeo Batoni (1708-1789) para a Basílica da Estrela e à contratação do tenor Luigi Giglioni para a Patriarcal de Lisboa, confirmando a primazia de Itália na importação de artistas e músicos.

No mês de junho de 1784 estavam em curso as negociações com Batoni relativas às últimas três pinturas para a basílica da Estrela; 9 Diogo de Noronha (1747-1806), ministro plenipotenciário em Roma, recebeu precisas instruções acerca do tema dos últimos três quadros que o pintor originário de Lucca pintaria para D. Maria I. O programa iconográfico, que a rainha determinara com a aprovação do seu influente confessor, o arcebispo Inácio de São Caetano (1719-1788), foi enviado a Roma juntamente com o pedido de «buscar nessa Itália bum bom retrattista "10 disponível a mudar-se para Lisboa; desejava-se um bom pintor italiano, mas não era necessário que estivesse a trabalhar em Roma, ao contrário do que acontecera em 1779 com a

\footnotetext{
${ }^{8}$ Espanha, Patrimonio Nacional, Inv. n. ${ }^{\circ}$ 10089503: Maria I de Portugal [4,2 x 3,5 cm]; Inv. n. ${ }^{\circ}$ 10089502: João de Bragança [4,5 x 3 cm]; Inv. n. ${ }^{\circ}$ 10089508: Infanta Carlota Joaquina de Borbón [4,5 x 3 cm].

9 Pelo que diz respeito à cronologia das encomendas a Batoni, lembramos que a primeira, para o retábulo do altar-mor, remonta a 1779; em 1782 foram encomendadas as pinturas da Última Ceia, A ceia de Emmaus e o São Tomás. Em 1784 é a vez de o Sonho de São José, o São Francisco e Santo António e o São João Evangelista. RAGGI, G. (2002), As pinturas de Pompeo Batoni: Status Quaestionis, em "Documentos", 3/2002, pp. 46-53

${ }^{10}$ ANTT, MNE, Cx.830, rascunho, 29 de junho de 1784
} 
encomenda da pintura para o altar-mor da basílica da Estrela. Nesse caso a escolha de Pompeo Batoni foi ad personam.

Para o cargo de retratista, Noronha contactou num primeiro momento Anton Von Maron (1733-1808)11, mas este exigiu uma remuneração exorbitante de "Scudi Romani cinquemila [...] Casa ammobigliata, da potersi abbitare, e vi siano vani da poterne formare dei studi ad uso di Pittore, e col dovuto lume, per se, e quei Allievi, che dovrá istruire [...] la carrozza di corte [...] che il suo Onorario principi a correre dal giorno che egli si stacca da Roma [...] che la Corte si assommi il pensiero di far trasportare esso Antonio de Maron, e sua moglie, con bauli e casse spettanti a loro, ed alla sua Professione, da Roma fino a Lisbona». ${ }^{12} \mathrm{O}$ falhanço das negociações levou o ministro a procurar um artista nas cortes de Nápoles e Turim, onde obteve informações acerca de um bom pintor e ótimo miniaturista. ${ }^{13}$ Giuseppe Trono, que nessa altura estava ao serviço de Vítor Amadeu de Saboia como pintor de retratos e miniaturas, ${ }^{14}$ deve ter achado a proposta da corte portuguesa suficientemente aliciante para tomar a decisão de deixar Turim. As poucas fontes existentes referem que o artista regressara ao Piemonte em 1782 após uma ausência de dezoito anos, sete dos quais vividos em Roma, trabalhando como pintor de miniaturas, e os restantes em Nápoles, onde retratou em várias ocasiões a família real. A longa permanência em Roma explicaria o facto de Noronha, ao avaliar o talento de Trono, afirmar ter visto numerosas obras

\footnotetext{
11 ANTT, Arquivo Casa Real (ACR), Cx. 3505.

12 ANTT, ACR, Cx. 3505, Carta autógrafa de Anton Von Maron de 17 de julho de 1784 .

13 ANTT, ACR, Cx. 3505. Carta de 2 de setembro de 1784, de Diogo de Noronha para Pinto da Silva.

14 Trono recebia um salário de trezentas liras anuais. BAUDI VESME, A. (1968), Schede Vesme. L'arte in Piemonte dal XVI al XVIII secolo, Società piemontese di Archeologia e Belle Arti, Vol. III, Torino, p.1057.
} 
suas excelentes, ${ }^{15}$ porventura em casa de diplomatas que o artista piemontês retratara no passado.

A rede de contactos posta em ação em Turim levou à escolha de Giuseppe Trono, que se apressou a comunicar ao ministro em funções na corte piemontesa, Rodrigo de Sousa Coutinho (1775-1812), a sua satisfação pelo cargo. Sousa Coutinho escreveu para a corte que «Havendo remetido Piaggio huma carta p. ${ }^{a}$ o Pintor Retratista Trono, este veio verme, e me disse que se achava felismente escriturado ao serviço da Nossa Corte, e que brevemente partiria [...] Pareceme, segundo o juizo que aqui oiço dos seus talentos, que a nossa Corte fas huma muito boa acquizição». ${ }^{16}$ O contrato, que o cônsul de Portugal em Génova, Giovanni Piaggio, redigiu em dezembro, por ordem de Diogo de Noronha, foi autenticado por Sousa Coutinho no mês de janeiro. Piaggio escrevera para a corte em dezembro, informando que Giuseppe Trono fora contratado com "pello ordenado de settecentos mil reis por Anno, e a quantia de trezentos Escudos romans para ajuda da custo, pellos gastos da viagem» ${ }^{17}$ e com a cláusula de se apresentar em Lisboa até ao fim de março, uma urgência devida ao avizinhar-se do casamento entre a infanta Carlota Joaquina e o príncipe D. João, marcado para o mês de junho. O encontro seguinte entre Trono e Piaggio é documentado pelo recibo, autógrafo, do

15 ANTT, ACR, Cx. 3505, carta de Diogo de Noronha de 9 de setembro de 1784, antes em Documentos (1936), Boletim da Academia Nacional de Belas-Artes, Lisboa, p. 68 .

16 ANTT, MNE, Cx. 862. A carta de 15 de dezembro de 1784 , é citada em Rodrigues, Soares (2014, p.196)

17 A carta de Piaggio para o guarda-joias José António Pinto da Silva, redigida em português, é de 20 de dezembro de 1784. O texto do contrato, redigido em italiano, especifica que: «Io, Giovanni Piaggio [...] in virtù degli ordini, e facoltà conferite dall'Ill.mo Sig. Diogo de Noronha [...] di poter trattare, ed ammettere per il suo Reale Serviggio il Sig. Giuseppe Trono di Torino in qualità di Pittore Ritrattista per doversi portare in Lisbona, e servire in tutto quello gli verrà di Regio Ordine comandato, ed ordinato, mediante l'onorario di Settecento mila Reis per ogni anno, per doverle durare, e continuare detto onorario, per tutti quegli anni, e tempo che piacerà alla Maestà sua di tenerlo al suo Reale Serviggio. [...]" Soares (1935, pp. 8-9). O pagamento da renda cabia ao pintor. 
pagamento das despesas de viagem; ${ }^{18}$ Trono embarcou em Génova, em 9 de fevereiro de 1785, chegou a Madrid em 21 de fevereiro ${ }^{19}$ e seguiu para Lisboa, apresentando-se na corte no prazo estabelecido.

Em 21 de abril Diogo de Noronha pedia instruções acerca do envio de um quadro que Batoni concluíra, a tela do Sonho de São José para a basílica da Estrela, que, exposto ao público, «tem merecido a aprovação geral ${ }^{20}$ », fora muito apreciado também pelo príncipe Nikolai Borisovic Yussupov, influente figura da aristocracia russa nessa altura em missão diplomática em Roma, grande connoisseur e colecionador ${ }^{21}$. Noronha aproveitou a ocasião para referir que justamente o ilustre Yussupov lhe confirmara a fama e o talento de Trono: «Tambem ouvi com grande gosto o sobredito Principe, que o pintor Trono, que mandei para essa Corte, e que agora la se achará, era reputado em Turim, aonde estava por hum dos melhores, e que ele julgava que assim parecia em toda a parte».22 Entretanto a notícia do cargo de Trono como retratista da corte portuguesa difundira-se no meio artístico de Roma, como atesta um comentário do pintor Gaspare Landi (1756-1830): "Il cavaliere de Maron, che certamente non é Tiziano, ha chiesto seimila scudi romani per anno, ed altri articoli che fanno crescere di molto questa somma, per andare in Portogallo; somma che per altro é parsa esorbitante a quella corte, cosicché hanno nel sig Dron (sic!), torinese, pittore mediocrissimo,

18 ANTT, ACR, Cx. 3505, Recibo autógrafo com data de 7 de fevereiro de 1785.

19 ANTT, ACR, Cx. 3505, carta de Piaggio de 22 de março de 1785.

20 ANTT, MNE, Cx. 830, Of.17 de 21 de abril de 1785.

21 Trata-se do príncipe russo Nikolai Borisov Yussupov (1751-1831), embaixador em Turim entre 1783 e 1788 e desde 1785 em missão também junto da Santa Sé. Em Roma Yussupov frequentava o atelier de Batoni na rua Bocca di Leone, e encomendara-lhe dois quadros que representavam Vénus e Cupido. CLARK, A. (1985) Pompeo Batoni: a complete catalogue of his works with an introductory text edição de E.P. Bowron, Phaidon, Oxford, p. 361.

${ }^{22}$ ANTT, MNE, Cx. 830, Of.17 de 21 de abril de 1785. 
impiegati soli mille annui scudi romani». ${ }^{23} \mathrm{O}$ juízo severo põe em luz a concorrência feroz entre os artistas na Roma cosmopolita, onde as encomendas para as cortes estrangeiras eram muito desejadas, e confirma que, apesar da apreciação negativa, Landi conhecia o trabalho de Trono.

Segundo as informações que Cirilo Volkmar Machado (1748-1823) fornece na sua Coleção de Memórias ${ }^{24}$, Giuseppe Trono gozava de um certo prestígio em Lisboa também no meio aristocrático e da fidalguia; das obras que lhe foram encomendadas nesse âmbito ficam os retratos até hoje identificados e que confirmam a fidedignidade da fonte. De resto, Machado deve ter conhecido Trono, pois ambos frequentaram, como outros artistas e literatos, a casa do cônsul holandês Rouks, e neste aspeto a breve biografia da Colecção revela-se muito valiosa. Nela afirma-se igualmente que Trono trouxera de Turim vários quadros pintados pelo pai Alessandro «alguns no estylo de Solimena, outros no gosto de Vouet» e que possuía numerosas cópias a óleo e em miniatura de obras de Rafael, de Ticiano e dos grandes mestres por ele pintadas, porventura nas suas estadias em Roma e em Nápoles, e durante as viagens pela Itália25. É possível que Trono utilizasse as cópias nas aulas que dava aos seus alunos, se é verdade que a mulher do cônsul Rouks, a pintora Maria Leonor, fez uma cópia delas, como escreve Machado: um dado a ter em conta para a difusão dos cânones estéticos num país como Portugal, que na altura era ainda carente na área do ensino artístico e do mercado de objetos de arte.

23 Baudi Vesme (1968, vol. 3, p.1058). A carta de Landi é de 24 de novembro de 1786.

24 Machado (1823, pp.129-33).

25 ANTT, ACR, Cx. 3505. O facto de Trono ter trazido quadros e outros objetos de Itália é plausível dadas as numerosas cartas de Piaggio que informam acerca do envio da volumosa bagagem do pintor, que foi remetida para Lisboa com o navio Providencia em março. Carta de Piaggo de 7 de março de 1785. 
Em 1808, após a partida da corte para o Brasil, Trono tentou em vão regressar à Itália e morreu em Lisboa dois anos mais tarde. Os seus bens foram leiloados e parte deles ainda se encontrava no mercado de objetos de arte em 1813: um património que incluía, como refere a Gazeta de Lisboa ${ }^{26}$, ouro, diamantes, quadros e miniaturas de vários autores, o que revela uma vida abastada. Os vinte e cinco anos passados na corte portuguesa foram proveitosos para o empreendedor pintor piemontês, como atesta a abundante produção pictórica que se identifica neste ensaio, atualmente conservada em museus, coleções privadas e outras instituições públicas, e que, como veremos, merece ser resgatada.

\section{Os retratos da família real portuguesa}

Mal chegou a Lisboa, Giuseppe Trono teve de realizar uma intensa atividade pictórica. A ocasião do duplo casamento serviu de catalisador para enriquecer a coleção da família real. Atesta-o o facto de, a partir de junho de 1785, uma sala nos aposentos da rainha D. Maria I passar a ser indicada nos documentos de despesa do palácio real como "Casa dos Retratos". ${ }^{27} \mathrm{O}$ aparecimento da denominação de um lugar específico para a execução dos retratos testemunha a sua intensificação e deve ser associado à chegada a Lisboa, no mês de março, de Giuseppe Trono.

Ao analisar os retratos identificados para a redação deste ensaio, é possível encontrar alguns traços característicos do estilo

${ }^{26}$ A Gazeta de Lisboa de 27 março e 4 abril de 1810, e 27 de novembro de 1813. SANTOS, P. Mesquita (1999), Giuseppe Troni e Pellegrini entre outros retratistas da colecção Allen em "Revista de Guimarães", 109, p. 151.

27 ANTT, ACR, cx. 3139, Despesa de Junho de 1785, em ABECASIS, M. I. Braga (2009), A Real Barraca. A residência na Ajuda dos Reis de Portugal após o terramoto 1756-1794, Tribuna, Lisboa, p. 70. 
de Giuseppe Trono. Trata-se geralmente de retratos de aparato, pinturas de meio-corpo ou de corpo inteiro, que originam numerosos retratos de meio-busto em telas ovais ou retangulares. Nalguns casos foram encontrados apenas retratos de meio-busto, mas é muito provável que se tenham perdido ou continuem dispersas versões em formato maior. Nos retratos de corpo inteiro ou de meio-corpo os símbolos do poder são colocados de lado, em planos cobertos por preciosos veludos ou almofadas, e os retratados seguram-nos ou apontam para eles. Em particular, é constante o trompe l'oeil de documentos de papel (antigos pergaminhos, desenhos de projetos arquitetónicos ou pictóricos, mapas). Outro traço característico é o fundo uniforme, com tonalidades escuras e apenas movimentado por um cortinado lateral cromaticamente homogéneo. Na biografia publicada por Cyrillo Volkmar Machado lê-se que Giuseppe Trono «[...] Copiou a cabeça para o retrato que fez de corpo inteiro da mesma Senhora [a rainha Maria I]". ${ }^{28}$ A partir desta afirmação as raras referências críticas à obra de Trono e, sobretudo, ao retábulo da capela da Bemposta, arrasam os seus retratos da rainha D. Maria I considerando-os meras cópias do quadro pintado por Thomas Hickey em 1783.29 A realidade, porém, é muito diferente e o estudo dos vários retratos da família real, reunidos pela primeira vez neste ensaio, revela inesperadas dinâmicas de produção que abrangem também a gravura e a miniatura.

28 Machado, 1823, p.130.

29 MOITA L. (2005), A Bemposta. O "Paço da Rainha", edição de D. Markl, Livros Horizonte, Lisboa. FRANÇA J. A. (1967), A arte em Portugal no século XIX, vol. I, Bertrand, Lisboa. 


\subsection{A rainha D. Maria I (1777-1792)}

Maria de Bragança foi a primeira mulher a subir ao trono desde a fundação do reino de Portugal. Filha de D. José I (1750-1777) assistira à ascensão do secretário de estado José Sebastião de Carvalho e Melo, conhecido como marquês de Pombal ${ }^{30}$. Nos primeiros anos do seu governo, D. Maria I enfrentou um intenso processo de reajustamento das forças de poder, mudou estratégia política em relação aos Grandes de Portugal, enquanto deu continuidade a projetos científicos e artísticos que surgiram quer durante o reinado do seu pai, quer no anterior do seu avô paterno D. João V. Em 1779 foi fundada sob o seu patrocínio a Real Academia das Ciências, inaugurando a fase mais ativa e serena do seu reinado que sofreu um revés em 1788 em âmbito familiar, com os numerosos lutos devidos à epidemia de varíola, ${ }^{31}$ e também no âmbito institucional da monarquia por causa dos acontecimentos franceses de 1789. D. Maria I (1734-1816) exerceu as suas funções de monarca até ao ano de 1792, sendo primeiro coadjuvada na regência pelo filho D. João e sucessivamente substituída pelo mesmo.

Cronologicamente os retratos da rainha D. Maria I pintados por Trono inserem-se neste espaço temporal, mais precisamente de 1785 até 1793, ano em que se conclui a remodelação da capela régia da Bemposta. O já mencionado retrato da rainha, da autoria de Thomas Hickey (1741-824), que Caetano Beirão identificou com o quadro que atualmente se encontra na sala das Sessões da Academia Nacional das Ciências, ${ }^{32}$ foi realizado durante a estadia do pintor irlandês

${ }^{30}$ MONTEIRO, N. (2008), D. José: na sombra de Portugal, Temas e Debates, Lisboa.

31 Após a morte do consorte D. Pedro III em 1786, em setembro de 1788 faleceu o filho herdeiro do trono, José, e poucos meses depois a filha Mariana e o genro espanhol Gabriel de Bourbon.

32 BEIRÃO C., (1944), D. Maria I, 1777-1792: Subsidios para a revisão da história do seu reinado, Empresa Nacional de Publicidade, Lisboa. 
em Lisboa, em 1783, enquanto estava à espera de embarcar para a Índia. 33 O cotejo com a pintura assinada por Hickey de Gérard Devisme e com a gravura de David Purry ${ }^{34}$ confirma a atribuição avançada por Beirão. ${ }^{35}$ Estilisticamente os retratos do pintor irlandês apresentam uma pastosidade cromática conduzida em modalidades mais matizadas e atmosféricas em relação ao estilo de Giuseppe Trono. Também o enquadramento é mais cenográfico: a utilização de colunas antigas, as paisagens à inglesa e as perspetivas sobre portos longínquos caracterizam os quadros pintados por Hickey em Portugal. Na tela de 1783 a rainha está sentada e é representada com os símbolos do poder mas sem exibir uma gestualidade áulica: a coroa está pousada numa almofada atrás do braço languidamente relaxado, enquanto a outra mão, deixada cair no regaço, segura o cetro com estudada despreocupação. O penteado, entrelaçado discretamente com um fio de pérolas, é natural e também o olhar é surpreendido numa expressão calma e vagamente introspetiva. A obra de Hickey transmite a imagem do mecenato esclarecido da rainha, mais do que a realeza em si.

Os retratos de Giuseppe Trono, por seu lado, cumprem a função de obras de aparato. D. Maria I é representada como rainha de Portugal, por isso a prioridade é dada à gestualidade eloquente e à riqueza de pormenores sumptuosos (joias, panos preciosos, penteados). Do conjunto das obras reunidas parece ser plausível que o pintor de Turim tenha realizado retratos de corpo inteiro, a partir dos quais tirou inúmeras variações de formato mais pequeno. Nas coleções régias do castelo sueco de Gripsholm encontra-se um retrato

33 Machado (1823)

34 BNP, E.131.V. A gravura contém a seguinte legenda: «T.Hickey pinxit. Ab.Girardet del. et sculp."

35 Não tendo sido autorizada a publicação do retrato de Hickey de D. Maria I, o leitor pode ter uma ideia aproximada do quadro consultando o site https://www. leme.pt/biografias/80mulheres/maria.jpg (consultado em 27 de junho de 2017). A esta pintura refere-se Cyrillo na biografia de Trono. 
de D. Maria I de corpo inteiro cuja autoria é claramente de Trono. A pose é assertiva e dinâmica. A rainha aponta com ar severo para a coroa e o cetro apoiados na almofada. Veste um Andrienne com amplos paniers escolhendo o modelo francês mais elegante destinado aos principais eventos oficiais nas cortes europeias do século XVIII. A opção pelo tafetá azul seguia as predileções da moda, assim como o penteado embelezado por cristas, tiras de renda que caem nas costas e pelo valioso broche. A joia que lhe cinge a cabeça é formada integralmente por diamantes, mostrando a riqueza proveniente dos vastos domínios ultramarinos portugueses. O tecido azul oferece ao pintor a oportunidade de mostrar o seu virtuosismo pictórico, quer nas incidências da luz no pano, quer na reprodução translúcida das aplicações, das fitas de cetim e dos bordados do colete. A escolha do vestido determina um tratamento do espaço mais articulado: o reposteiro ao fundo deixa entrever uma sala monumental, sugerindo a extensão do palácio régio. A pintura é cuidadosamente estudada para transmitir a imagem de D. Maria I como rainha entre os seus pares europeus. Embora não se conheçam, até à data, as circunstâncias concretas nas quais a pintura de Trono chegou à Suécia, a obra deve ser relacionada com o desejo do rei sueco Gustavo III de criar uma coleção de retratos dos reis europeus. Deve ter havido um pedido por parte do rei e por isso a datação pode ser fixada entre 1785, isto é depois da chegada de Trono a Portugal, e 1788. ${ }^{36}$ Trono soube satisfazer plenamente o pedido, conferindo à rainha uma expressão de forte vitalidade. A pintura decorou a sala de gala do castelo de Gripsholm e permaneceu in loco até finais do século XIX, como atesta uma fotografia da época. É provável que um retrato de corpo inteiro parecido com o enviado para a Suécia decorasse também

\footnotetext{
36 O castelo de Gripsholm, sede da Swedish National Portrait Gallery, abriga a coleção que o rei Gustavo III da Suécia começou em 1777, ano em que o monarca decidiu juntar no seu palácio os retratos dos reinantes europeus, que pediu aos seus pares. O último quadro chegou à Suécia em 1788.
} 
as salas do palácio real da Ajuda mas deve ter ardido em 1794. ${ }^{37}$ É preciso ter em conta que as pinturas mais importantes realizadas por Trono ornamentavam as salas do principal palácio real, embora a corte se deslocasse entre várias residências segundo um calendário previamente fixado.

A residência preferida por D. Maria I e pelo consorte D. Pedro III foi o palácio real de Queluz. Neste lugar encontra-se outro retrato de D. Maria I. ${ }^{38}$ [fig. 1] Atualmente em exposição na sala da música, apresenta a rainha de meio corpo e numa pose real mais discreta mas igualmente carregada de simbolismo. D. Maria I aponta para o cetro e a coroa pousados numa almofada de veludo, enquanto veste a faixa tricolor onde está pendurada uma valiosíssima Cruz da Ordem de Cristo cravejada de diamantes. O vestido é à moda francesa, de feitura mais sóbria mas enriquecido com pérolas e diamantes, que ornam também o penteado. Os bordados são pintados com precisão e requinte, qualidades que se espelham na trasparência táctil da fita de véu no penteado. O delineamento geral do quadro sintetiza os traços característicos dos retratos de Trono, em particular o fundo homogéneo com reposteiro lateral em tonalidades escuras.

Características semelhantes às da tela de Queluz encontram-se também em dois retratos iguais, que pertencem respetivamente ao Museu de Évora e ao Museu da Cidade de Lisboa39. O primeiro integra um conjunto de três pinturas de iguais dimensões, atualmente em depósito na Embaixada portuguesa de Brasília e do Rio de Janeiro, que representam o príncipe D. João e Carlota Joaquina; por sua vez, o retrato da rainha, no Museu da Cidade, parece ser uma réplica do que se encontra agora no Rio de Janeiro. D. Maria I

37 Abecasis (2009). Raggi (2017), Dalla scuola di Carlo Fontana ai circuiti europei dei Galli Bibiena: architetti italiani in Portogallo nel XVIII secolo, em "Estudos Italianos em Portugal", 12.

38 Inv. PNQ 54.

39 Inv. ME 39 e Inv. MC.PIN.0236 


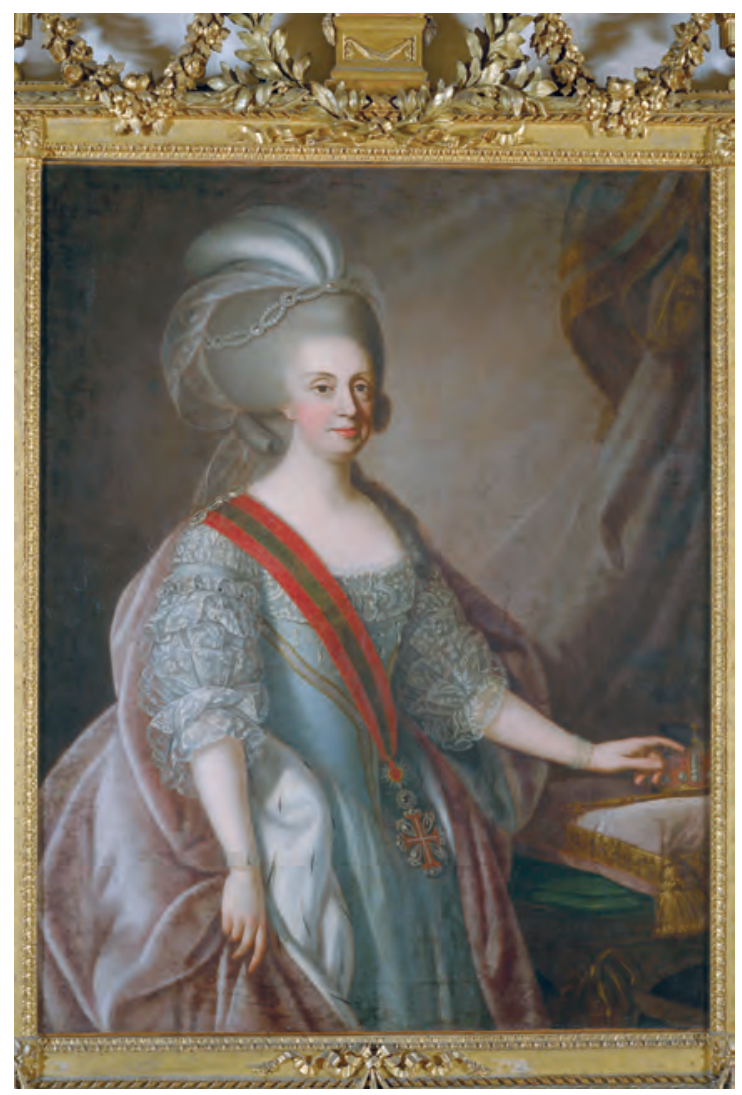

Figura 1 - Giuseppe Trono, Retrato de Maria I, ca. 1785, Queluz, Palácio Nacional, (c) DGPC, foto: José Pessoa

veste um traje semelhante ao da tela de Queluz, embelezado por um laço no penteado. Repete-se a mesma composição de meio-corpo, enquanto a atitude em relação aos símbolos do poder é mais ativa. A rainha pousa o cotovelo na almofada onde está colocada a coroa, segurando o cetro na vertical e pousando-o sobre dois papéis onde está escrito: "Maria Regina Fidelissima”, isto é o título que o papa concedeu em 1747 após longa insistência diplomática de D. João V, e "Cortes de Lamego", que remete para o documento fundador da monarquia portuguesa, na realidade um falso forjado no século XV, mas que foi sempre invocado para afirmar o direito 
à soberania. ${ }^{40} \mathrm{Um}$ retrato de meio-busto em tela oval, tirado das duas obras descritas, é conservado no Museu dos Coches de Lisboa e faz parte da produção original de Trono. ${ }^{41}$

A cuidadosa análise dos retratos de D. Maria I pintados por Giuseppe Trono revela um conjunto de variações, não apenas no enquadramento, mas também nas poses, nos gestos ou nos vestidos e nas joias, e uma sagaz modulação da expressão do rosto que pode escapar a um primeiro olhar, também pelo facto de se manter constante a sua direção (da esquerda para a direita) e o grau de rotação (levemente de três quartos), o que levou os anteriores estudos críticos a propagar tout court a afirmação de Volkmar Machado acerca da reprodução do rosto pintado por Hickey, ${ }^{42}$ enquanto a descrição até aqui apresentada dos retratos de D. Maria I confirma o papel ativo que Trono desempenhou na construção da imagem da rainha portuguesa.

\subsection{Os príncipes e as princesas do Brasil}

Na segunda metade da década de oitenta, o equilíbrio político e familiar que caracterizara os anos anteriores sofreu um revés. Depois do dúplice casamento entre as casas reais de Bragança e Bourbon celebrado em 1785, uma série de graves lutos afetaram a família real. Em 1786 morreu D. Pedro III, tio paterno e consorte de D. Maria I; em 1788, no espaço de três meses, morreram de varíola o príncipe herdeiro D. José (1761-1788), a infanta Mariana e o seu marido Gabriel António de Bourbon, com quem casara em 1785; a estas

${ }^{40}$ D. Maria foi a primeira rainha na história de Portugal, dado que D. José I não tivera descendentes masculinos.

41 Inv. HD 0017.

42 Moita (2005). 
mortes juntou-se a do confessor Inácio de São Caetano, conselheiro espiritual da rainha. Além do drama íntimo da rainha, toda a linha de sucessão do poder ficou de repente destruturada. D. José tinha sido educado como futuro rei e em 1777, com 15 anos, casara com a sua tia materna Maria Francisca Benedicta de Bragança (1746-1829).

O título de Príncipe e Princesa do Brasil designava os herdeiros do trono, e passou para o infante D. João (1767-1826) e a sua jovem esposa Carlota Joaquina (1775-1830), com a qual casara em 1785. De segundo membro da famíla real, D. João passou para o palco da vida política e teve de enfrentar a progressiva incapacidade da mãe para manter o ónus do governo político da monarquia e do império. A instabilidade psíquica de D. Maria I, que se manifestara depois de 1788, levou D. João a assumir em 1792 a regência informal e em 1799 a regência formal.

Neste complexo quadro dinástico inseriu-se a obra de retratista da família real de Giuseppe Trono, que acompanhou o crescimento de alguns dos seus membros assim como testemunhou o falecimento de outros.

2.2.1. O príncipe do Brasil D. José e a princesa viúva Francisca Benedita

Os retratos de meio-busto do herdeiro do trono de Portugal que podem ser atribuídos a Giuseppe Trono são, por agora, cinco, conservados respetivamente no palácio real de Queluz e no Hospital dos Inválidos Militares de Runa, no Museu de Évora, no Ministério dos Negócios Estrangeiros e no Museu Histórico do Rio de Janeiro. Pelo aspeto juvenil do príncipe e pela escrita em espanhol na parte posterior da tela de Queluz é possível datá-la com a de Runa de 1785. O terceiro retrato foi encomendado expressamente à corte pelo seu precetor, o erudito frei Manuel do Cenáculo, para lembrar o seu 
discípulo depois da morte prematura; deve ser por isso datado de 1788. ${ }^{43}$ As três telas reproduzem o mesmo retrato: D. José é representado em meio-busto com a Cruz da Ordem de Cristo cravejada de diamantes e o Tosão de ouro pendurados no peito, dando clara primazia visual à condecoração portuguesa.

O único retrato de meio-busto do príncipe D. José até agora conhecido foi recentemente descoberto no Brasil, e pertence ao Museu Histórico Nacional do Rio de Janeiro. As excelentes qualidades pictóricas e estilísticas da tela justificam a atribuição a G. Trono.

Muito mais retratada é a sua esposa que teve uma longa vida. São seis os retratos de Maria Francisca Benedita atribuíveis a Giuseppe Trono. Também neste caso não foram identificados, até à data, retratos de aparato de corpo inteiro ou de meio-corpo. Todas as obras reunidas enquadram a princesa em meio-busto. Ao contrário do que se verifica com os retratos do marido, as seis telas acompanham a passagem do tempo e transmitem visualmente a perda do esposo e a mudança de estatuto na corte.

Dois retratos, que pertencem respetivamente ao Museu dos Coches de Lisboa e ao Hospital dos Inválidos de Runa, podem ser datados como sendo anteriores ao ano de 1788 . O primeiro, mais elegante e rico, representa a imagem da futura rainha: o penteado, embelezado pelo véu e pela joia de pérolas entrelaçadas, é semelhante ao exibido por D. Maria I no retrato de Queluz, enquanto se deixa entrever uma ponta do manto real. ${ }^{44} \mathrm{O}$ rosto é jovem e sereno e corresponde à fisionomia e à expressão do retrato de Runa. Neste último caso a princesa aparece com um simples penteado com pó-de-arroz,

43 Não foi possível examinar em pormenor o retrato de Évora (Inv. ME 657). A imagem pode ser consultada no site http://www.matriznet.dgpc.pt/MatrizNet/ Objectos/ObjectosConsultar.aspx?IdReg=15408 (acesso em 15 de junho de 2017).

${ }^{44}$ A atribuição do Museu dos Coches (Inv. HD 0019) ao pintor francês Jean-Baptiste Debret (1768-1848) está errada dado que implicaria uma datação posterior a 1816, ano em que Debret chegou ao Rio de Janeiro. 
vestida à "moda inglesa", ou seja com redingote embelezada com simples rendas brancas apta para a caça e a equitação, atividades que Francisca Benedita praticava com assiduidade. A inclinação para a vida ativa era partilhada pelo jovem marido que se interessava sobretudo pela arte militar e pelo desenvolvimento manufatureiro do reino, um assunto sobre o qual trocou densa correspondência com Rodrigo Sousa Coutinho, quando este último desempenhava o cargo de embaixador em Turim. ${ }^{45}$ Em 1792, em memória do marido, Francisca Benedita encomendou ao arquiteto José da Costa e Silva, aluno da Accademia Clementina de Bolonha, o projeto do Hospital militar de Runa, uma localidade próxima das principais linhas de defesa de Torres Vedras. Provavelmente a ideia era um dos projetos de governo do marido, que Francisca Benedita conseguiu realizar por ter mantido o título de princesa-viúva do Brasil com as elevadas rendas que implicava. O complexo arquitetónico é uma das obras mais importantes que José da Costa e Silva projetou e concluiu, tendo sido inaugurado após o regresso da corte do Brasil. ${ }^{46}$ Percebe-se, então, por que motivo o retrato da princesa faz pendant com o do príncipe D. José conservado no mesmo lugar. [fig. 2]

Com o período da viuvez deve ser relacionado o retrato recentemente descoberto numa coleção privada. [fig. 3] O decoro, os tons cromáticos do vestido e a ponta melancólica na expressão justificam uma datação posterior a 1788, confirmada também pela ausência de joias no penteado e pela maior sobriedade do traje. Por fim, a princesa-viúva é retratada em mais três telas que apresentam a mesma efígie. Uma delas integra uma coleção privada enquanto as

45 MANSUY-DINIZ A. (2002), Portrait d'un homme d'État: D. Rodrigo de Souza Coutinho Comte de Linhares, 2 Vols., Centre Culturel Calouste Gulbenkian, Lisbonne-Paris.

46 Acerca disto veja-se TEIXEIRA J. de Monterroso (2012), José da Costa e Silva (1747-18198) e a receção do neoclassismo em Portugal: a clivagem de discurso e a prática arquitetónica, Tese de doutoramento, Univ. Autónoma de Lisboa. 

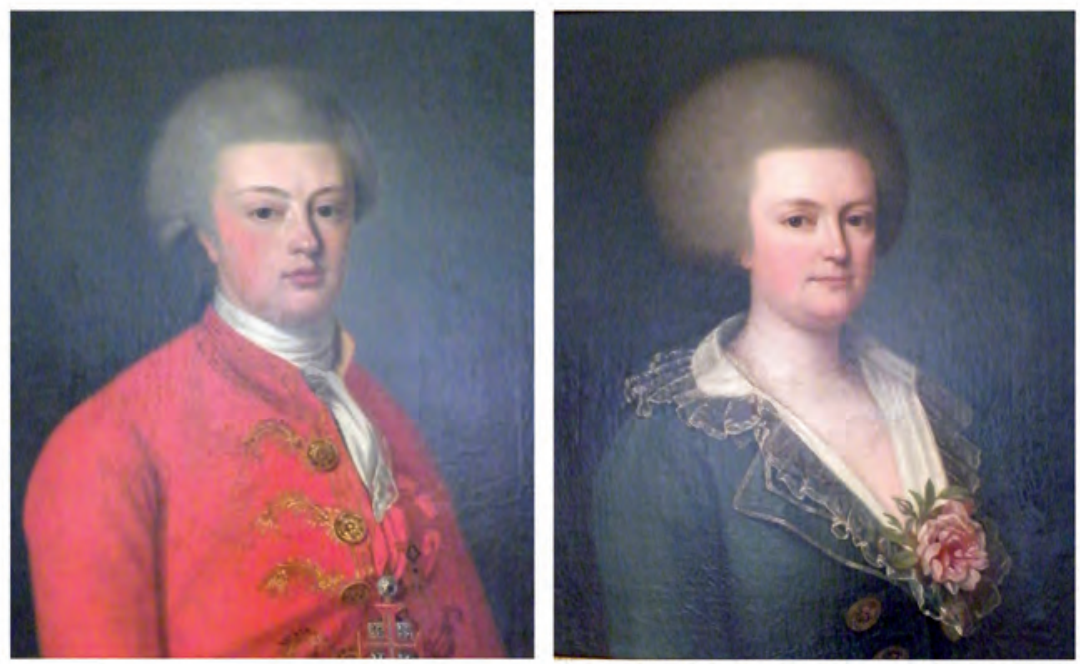

Figura 2 - Giuseppe Trono, retratos dos príncipes do Brasil D. José e D. Maria Francisca Benedita, ca. 1785, Runa, Hospital dos Inválidos Militares

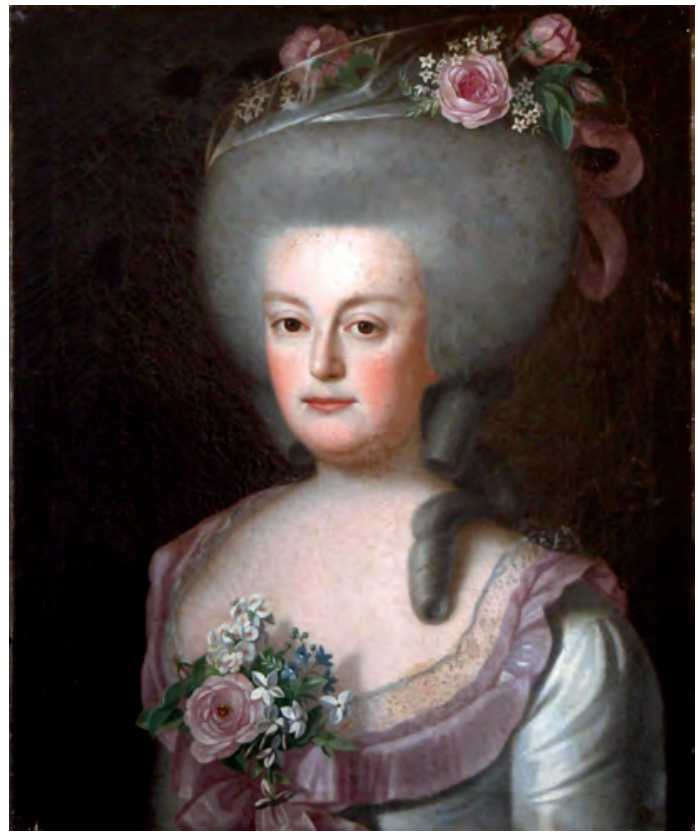

Figura 3 - Giuseppe Trono, retrato da princesa D. Maria Francisca Benedita, post 1788 , Lisboa, Coleção privada 
outras duas apareceram recentemente no mercado de objetos de arte. ${ }^{47} \mathrm{~A}$ expressão do rosto é mais marcada, a tonalidade do vestido e dos véus é da cor de marfim, embelezada por joias e flores no penteado e por um broche de diamantes na capa de organdi que lhe cobre as costas. Os retratos são em meio-busto, mas na realidade as três telas retomam a imagem de corpo inteiro pintada por Giuseppe Trono na grande tela do altar-mor da Bemposta.

\subsubsection{O infante e príncipe do Brasil D. João e a sua esposa Carlota} Joaquina de Bourbon

No Museu Soares dos Reis do Porto encontram-se dois retratos em meio-busto de D. João e Carlota Joaquina que datam da época em que eram o casal de infantes da família real, ou seja antes de 1788. Nos catálogos do século XIX estas duas pinturas foram atribuídas ao pintor Francisco Vieira, cognominado o Portuense, mas a sua autoria foi devolvida a Giuseppe Trono. ${ }^{48}$ D. João mostra um aspeto juvenil, um rosto ainda não pingue e a testa ampla que o distingue do irmão D. José. Como este último veste um casaco com grandes botões em que ressalta a cruz da Ordem de Cristo. A boca semicerrada confere vivacidade à expressão e propõe o mesmo recurso utilizado por Trono nos retratos do príncipe D. José. Nas coleções do palácio real de Vila Viçosa, propriedade originária da família Bragança, existe um retrato semelhante, ${ }^{49}$ e nas coleções espanholas encontra-se a

${ }^{47} \mathrm{Em} 2013$ e em 2017 os dois retratos foram vendidos pela sociedade de leilões Cabral Moncada.

48 Santos (1999).

49 TELLES, P. Delayti (2015), Retrato entre baionetas: prestígio, política e saudades na pintura do retrato em Portugal e no Brasil entre 1804 e 1834, Tese de Doutoramento, Universidade de Évora. 
miniatura correspondente, pintada por Trono em marfim, na qual a vivacidade do aspeto aparece mais intensa pelas cores brilhantes.50

A um período próximo da primeira regência, ou seja os primórdios dos anos noventa do século XVIII, deve ser associado um retrato de meio-corpo pertencente à coleção da Biblioteca Nacional de Portugal que, até à data, não fora identificado ${ }^{51}$ Tendo em conta as características e a pose é possivel datá-lo do período em que D. João já se tornara príncipe do Brasil. O aspeto corresponde à fisionomia conhecida e a identificação é confirmada também pela afinidade da pose e a semelhança com o retrato conservado na Academia das Ciências, cuja datação é posterior a 1792, por causa da faixa com as cores das três ordens de cavalaria. O manto confirma a investidura. Provavelmente o quadro foi pintado para celebrar o novo protetor da Academia, da mesma forma como a mãe D. Maria I tinha sido representada por Thomas Hickey em 1783. Neste retrato o príncipe D. João pousa a mão sobre uns volumes dedicados às ciencias matemáticas de Euclides, una referência clara ao incentivo da cultura científica que a Academia visava. Estas duas pinturas apresentam a mesma corporatura e a mesma tipologia do traje: o colete e o casaco são bordados ao longo das orlas e em redor das casas dos botões ricamente trabalhados. Numa perspetiva estilística, em ambas as pinturas nota-se uma evidente diferença qualitativa entre a execução do rosto e a pose do corpo, e também os reflexos e as sombras do tecido do casaco bordado resultam apagados e incertos em relação à alta qualidade patenteada nas pinturas de autoria segura de Trono. De facto a execução da pose do corpo e da riqueza táctil dos tecidos não podem ser comparados com o retrato de corpo inteiro do retábulo da capela da Bemposta, embora neste caso o príncipe regente apareça claramente mais pingue. As

\footnotetext{
50 Espanha, Patrimonio Nacional, Inv. 10089502.

51 BNP Inv. 10921.
} 
disparidades estilísticas sugerem a intervenção de ajudantes e alunos que, nos anos de maior atividade do pintor na corte, não só aprendiam a arte conforme estava estabelecido no contrato, mas também participavam diretamente no ciclo de produção, tratando das partes menos difíceis. Um último retrato associado ao primeiro periodo da regência pertence ao Museu de Évora e atualmente encontra-se em depósito na Embaixada portuguesa de Brasília. O príncipe D. João tem os mesmos símbolos de poder dos retratos da Academia das Ciências e da capela da Bemposta e aponta para um conjunto de documentos.52

A pintura de Brasília faz pendant com a de Carlota Joaquina que se encontra na mesma embaixada. ${ }^{53}$ No retrato é representada ainda com o rosto de menina, mas aponta para uns mapas o que pode levar a fixar a data da pintura num período posterior a 1788 , ou seja numa altura em que a infanta espanhola já assumira o título de princesa do Brasil e, por isso, afirma com o gesto a sua nova condição de futura rainha. A infanta Carlota Joaquina é a figura que Giuseppe Trono retrata mais vezes, o que se explica quer pela sua idade quer pelos acontecimentos que mudaram de repente o seu destino e que a levaram a desempenhar o seu papel de rainha nas duas margens do oceano. A consorte espanhola de D. João de Bragança chegou à corte de Lisboa em 1785, com dez anos de idade. Era uma criança quando Trono pintou o seu retrato de corpo inteiro que constitui uma das suas obras melhores juntamente com o retábulo da Bemposta. Trata-se da tela atualmente conservada no Museo del Prado e atribuída a Giuseppe Trono na base de seguros

52 Inv. ME 40. Sobre a presença de obras de Giuseppe Trono no Brasil veja-se RAGGI G., DEGORTES M. (2018A), "A dispersão das pinturas de Giuseppe Trono nas colecções brasileiras: pistas para futuras investigações» in NETO M. J., MALTA M. (eds.) (2018), Coleções de Arte em Portugal e Brasil nos Séculos XIX e XX. Coleções em exílio, Caleidoscópio, Casal de Cambra.

53 Inv. ME 41. 
fundamentos estilísticos e documentais ${ }^{54}$ após ter sido considerada durante muito tempo obra de Salvador Maella, autor de outro retrato de Carlota Joaquina quando menina. $55 \mathrm{O}$ pintor piemontês realizou a pintura em 1787 e o quadro foi enviado para a corte de Madrid a fim de testemunhar a nova vida da infanta que leva pendurada no peito uma bela miniatura com o retrato do esposo. A tela foi exposta no palácio real de Madrid. Trono trabalhou esta obra com extremo requinte. $\mathrm{O}$ facto de estar destinada à corte espanhola para decorar as salas de retratos de família de aparato impunha a maior qualidade e é uma summa da arte do pintor piemontês, quer como modelo geral de composição quer como execução dos pormenores, e demonstra plenamente a sua habilidade em transmitir a sensação táctil dos tecidos brilhantes e os seus reflexos de luz.

Este retrato esteve na origem de uma série de variações. A mais interessante é o mencionado retrato de meio-corpo atualmente em Brasília, mas abundam as réplicas de meio-busto: até agora foram identificadas seis. Em graus diferentes esses seis retratos revelam intervenções de ajudantes e alunos de Trono como nos do príncipe D. João. ${ }^{56}$ A esses retratos em meio-busto deve-se acrescentar a miniatura, que integra as coleções espanholas, realizada por Giuseppe Trono. ${ }^{57}$

$O$ retrato de corpo inteiro na capela da Bemposta testemunha outra etapa do crescimento da infanta Carlota Joaquina, que já se tornara princesa do Brasil. Em 1792-1793 ela tinha cerca de dezassete anos e Trono retrata-a adolescente, na pose mais animada do

54 SANCHO, J.L. (2001), Francisco de Goya y Fréderic Quillet en el Palacio Real de Madrid, 1808, em "Boletín del Museo del Prado", XIX, 37, pp. 115-42.

$55 \mathrm{~N}^{\circ}$ Catalogo P02440 consultado em https://www.museodelprado.es/coleccion/ obra-de-arte/carlota-joaquina-infanta-de-espaa-reina-de/5dcdbf98-5320-4600-9f13-f581c44edca1 consultado em 10 de junho de 2017.

56 Nos dois retratos da Biblioteca Nacional e da Academia das Ciências.

57 Espanha, Patrimonio Nacional Inv. 10089508. 


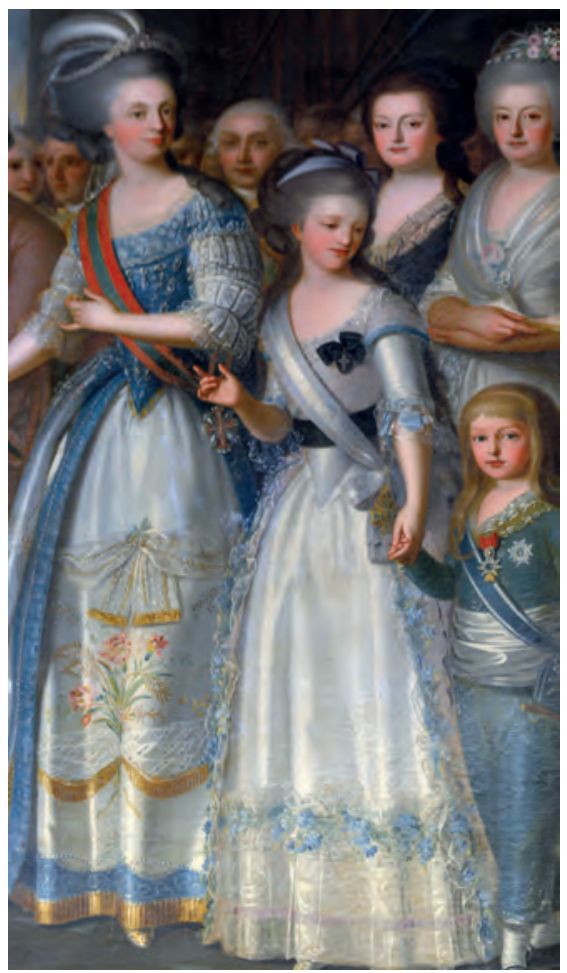

Figura 4 - Giuseppe Trono,

Consagração da monarquia portuguesa e do seu governo ao Sagrado Coração de Jesus (pormenor), 1791-1792, Lisboa, Capela da Bemposta

(C) Academia Militar, foto: João Vinagre

grupo familiar, enquanto segura pela mão o pequeno Pedro Carlos de Bourbon (1786-1812). Embora seja uma pintura oficial constitui certamente o retrato mais espontâneo da princesa. [fig. 4]

Poucos anos mais tarde foi retratada em meio-corpo noutra obra de Trono até hoje conhecida apenas através de gravura.58 [fig. 5] A pintura, na realidade, encontra-se na Academia das Ciências e é uma das obras melhores do pintor piemontês até agora identificadas59.

58 A gravura de M.Leitão Vasconcelos apresenta a legenda "Troni pinxit" e é de 1810. BNP, Inv. E. 92.V. http://purl.pt/4197/3/ Consultado em 29 de junho de 2017.

59 Infelizmente não foi dada a autorização para a reprodução desta tela, que num catálogo do século XIX foi atribuída a Domingos Sequeira. 
O estilo demonstra-o claramente: a composição geral sem recurso a enquadramentos arquitetónicos, a presença de desenhos com projetos pictóricos pousados debaixo da almofada, o brilho do cetim da faixa e a luz que incide na manga tufada fazem parte do estilo pictórico do piemontês. Também a pintura das joias, cuidadosa e cheia de reflexos de luz confirma a autoria da obra. O fundo mais claro, o baixo-relevo com três putti que brincam com um galgo, a lembrarem os da Camera della Badessa de Correggio, ${ }^{60}$ e, sobretudo, o vestido estilo império de Carlota Joaquina anunciam tempos novos. A jovialidade da expressão mantém a vivacidade do retrato da Bemposta, embora se manifeste com maior decoro pelo penteado de mulher adulta. A cronologia da pintura não pode ultrapassar 1795, ou seja o limiar dos vinte anos de Carlota Joaquina.

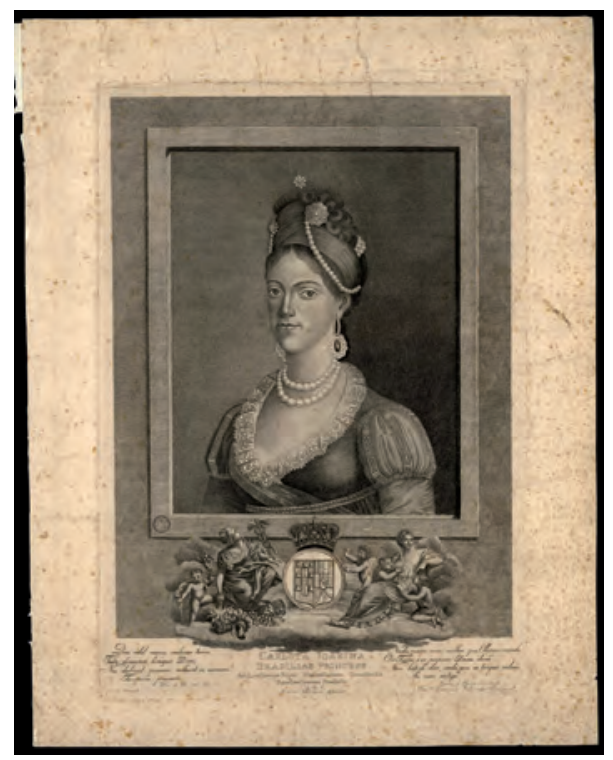

Figura 5 - Manuel Leitão de Vasconcelos, Carlota Ioakina Brasiliae Princeps, gravura, 1810, Lisboa, Biblioteca Nacional @ BNP E. $92 \mathrm{~V}$

${ }^{60}$ Convém lembrar que em 1795 o pintor Vieira Portuense trabalhou na edição bodoniana Pitture di Antonio Allegri detto il Correggio esistenti in Parma nel Monastero di San Paolo. 


\section{A capela real da Bemposta e a missão político-religiosa da monarquia portuguesa}

O painel para o altar-mor da capela do palácio real da Bemposta é, sem dúvida, a obra mais importante e significativa que Giuseppe Trono realizou em Portugal. ${ }^{61}$ [fig. 6] Os estudos histórico-artísticos prestaram-lhe escassa atenção e observaram-na superficialmente, considerando-a não homogénea e executada por três pintores diferentes. ${ }^{62}$ A dificuldade da leitura estilística e iconográfica é compreensível, sendo a obra de facto sui generis. Apresenta características específicas quer no plano da composição quer no do seu significado e a sua análise não pode prescindir da pintura que, em Roma, Pompeo Batoni executou para o altar-mor da basílica da Estrela. Estas duas obras datadas respetivamente de 1779-1781 e 1792-1793, ${ }^{63}$ constituem as obras pictóricas mais notáveis do reinado de D. Maria I.

Quando subiu ao trono, D. Maria I solicitou ao papa Pio VI a possibilidade de erguer uma basílica sob a invocação do Sagrado Coração de Jesus. O pontífice estava a dar um impulso decisivo para a difusão desse culto e em 1777 concedeu a instituição do rito no reino de Portugal e em todos os seus domínios, associando-o a uma nova liturgia que sublinhava o simbolismo da realeza. ${ }^{64}$ Iconograficamente, o coração «isolado como preciso objecto da liturgia» remetia para a assunção das virtudes e dos afetos da bondade

${ }^{61}$ Sobre esta obra veja-se RAGGI G., DESGORTES M. (2018B), A pintura de Giuseppe Trono na Capela do Paço da Bemposta - Academia Militar, Edições Colibri, Lisboa.

62 Moita (2005).

63 Sobre a história da encomenda para a Basílica da Estrela veja-se Raggi (2002), Clark (1985), AVERINI (1974), I dipinti di Pompeo Batoni nella Basilica del Sacro Cuore all'Estrela, em "Estudos Italianos em Portugal", Lisboa.

${ }^{64}$ MENOZZI, D. (2001), Un culto tra devozione interiore e restaurazione cristiana della società, Viella, Roma, pp. 50-51. 
de Cristo, reforçando "o vínculo indissolúvel entre a potencialização do poder monárquico e a atribuição à igreja da função legitimadora da soberania polítican. ${ }^{65} \mathrm{~A}$ escolha de Pompeo Batoni como autor do painel do altar-mor da basílica teve em conta o facto de o artista, ele mesmo devoto do Sagrado Coração, ter elaborado em 1765 para a igreja de Jesus a primeira iconografia do novo culto. Na pintura portuguesa o coração domina isolado ao centro e no ápice da tela.

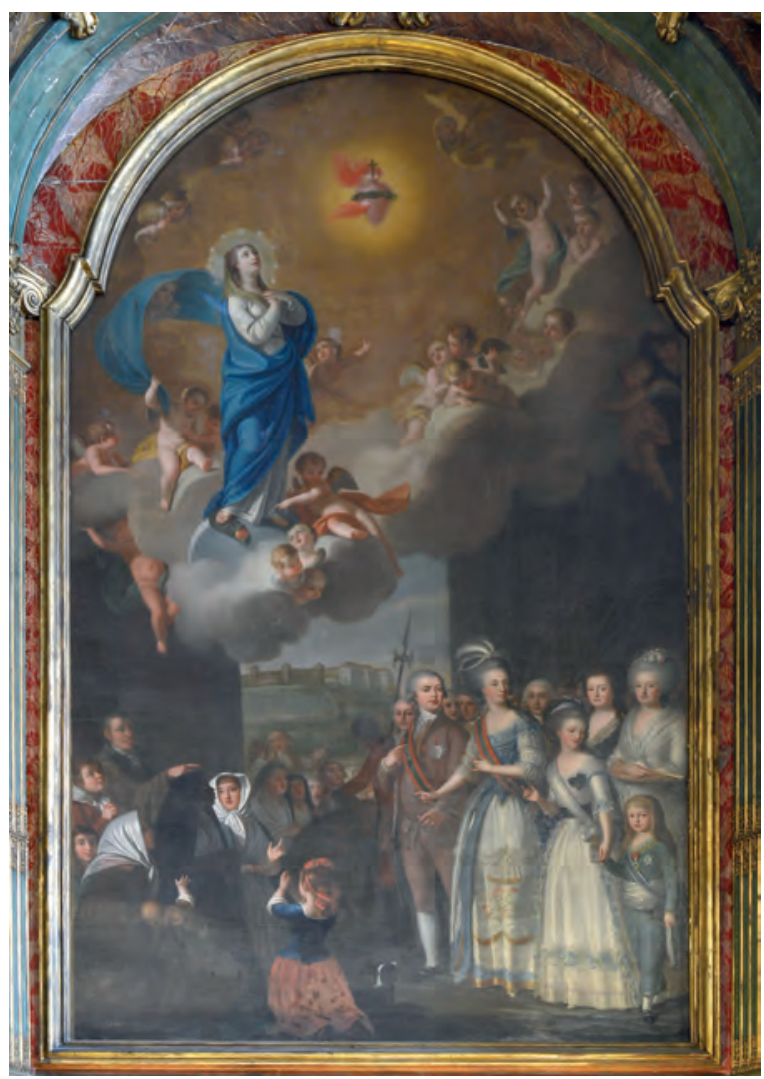

Fig. 6 - Giuseppe Trono,

Consagração da monarquia portuguesa e do seu governo ao Sagrado Coração de Jesus, 1791-1792, Lisboa, Capela da Bemposta (c) Academia Militar, foto: João Vinagre

65 Ivi. p. 52. 
No plano intermédio, à esquerda, Pio VI mostra ao mundo a fonte primeira do amor de Cristo, cuja luz atinge diretamente a eucaristia colocada no meio entre o pontífice e a alegoria da caridade. Em baixo, os quatro continentes são representados segundo uma diferente escala hierárquica: à direita sobressai a Europa, que monta um majestoso corcel, vestida como uma rainha com os símbolos do poder monárquico (a coroa e o cetro). ${ }^{66}$ Antes de ser enviada para Portugal a tela foi exposta no atelier de Pompeo Batoni, lugar ao qual o papa Pio VI se deslocou em 20 de outubro de 1781 para dar a sua aprovação. A Consacrazione del mondo al Sacro Cuore di Gesù chegou a Lisboa em 1782, enquanto a basílica estava ainda a ser construída, sendo consagrada apenas em novembro de 1789. Deste modo, em 1779, a primeira festa do Sagrado Coração em Portugal foi celebrada na capela real da Bemposta. A capela foi originariamente dedicada à Nossa Senbora da Conceição e durante as décadas de oitenta e do século XVIII foi completamente remodelada. ${ }^{67} \mathrm{Na}$ lápide colocada para comemorar o fim das obras, o Sagrado Coração não é mencionado espressamente mas aludido por meio de uma expressão que se refere, quer ao conteúdo do novo culto, quer ao papel do rei: "Ao Supremo Condutor das coisas e à Virgem concebida sem mácula de origem, este templo construído com belíssimo trabalho de arte, para sempre, doce monumento de religião consagrou João príncipe do Brasil, da gente lusitana esperança e desejo. Para a salvação. 1793". ${ }^{68}$ A composição da tela do altar-mor reflete o papel dominante do novo culto. Ao centro, isolado e no alto domina o coração com os elementos icónicos adequados (coroa de espinhos, chamas, cruz). No plano intermédio, à esquerda, a Nossa Senhora da Conceição contempla extasiada o

66 Ibid.

67 Moita (2005).

68 Transcrição em latim, traduzida para português em Moita (2005, p. 59). 
Sagrado Coração. Colocada na posição correspondente à do papa Pio VI na basílica da Estrela, esmaga a serpente rodeada de anjos em festa. Uma variação notável é a ausência de outras representações, como a Eucaristia e a Caridade, presentes na tela de Batoni. A composição adquire uma inusual disposição diagonal, libertando o espaço à direita e dando realce à representação da família real. O pequeno anjo que, das nuvens, olha divertido para baixo, interliga os dois níveis, sugerindo indiretamente a presença da Caridade encarnada pelos monarcas. Na terra, a representação personifica-se no retrato. Diante da família real é pintado um grupo de pessoas de extraordinária plasticidade. [fig. 7]

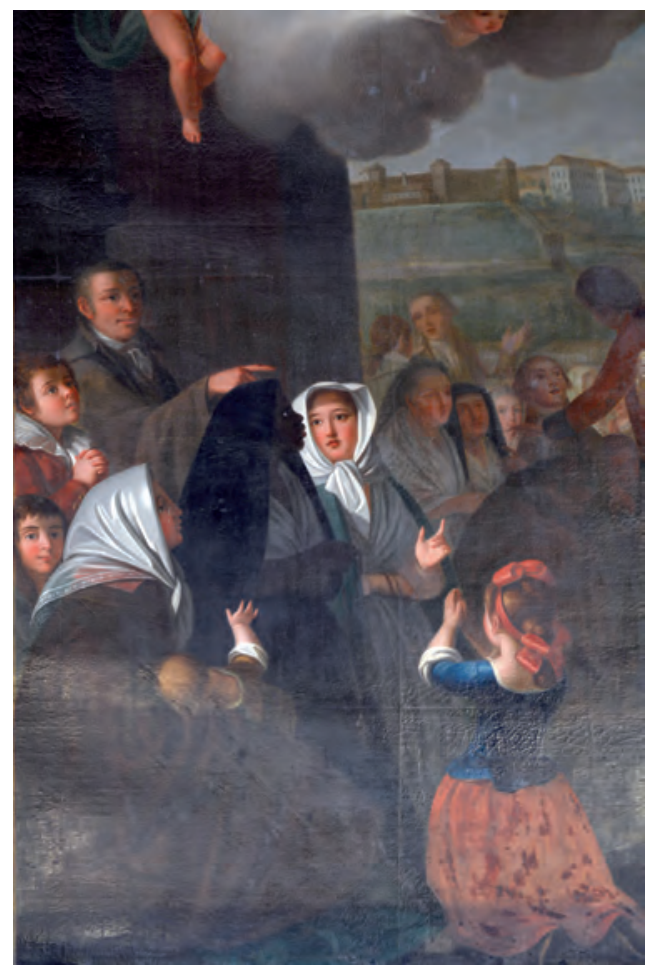

Figura 7 - Giuseppe Trono,

Consagração da monarquia portuguesa e do seu governo ao Sagrado Coração de Jesus (pormenor), 1791-1792, Lisboa, Capela da Bemposta (C) Academia Militar, foto: João Vinagre 
Os gestos e os olhares permitem entender as relações entre os dois grupos de retratos e entre as pessoas de cada grupo. A rainha D. Maria I olha para fora da tela, apontando para o príncipe D. João que, por sua vez, aponta para ela, também ele virando o olhar para a assistência. Ambos têm a faixa das três ordens que indica a condivisão do governo do reino, decidida em fevereiro de 1792 por causa da instabilidade mental da rainha. À esquerda, a princesa Carlota Joaquina aponta a rainha ao pequeno Pedro Carlos de Bourbon, filho órfão de Mariana de Bragança e Gabriel de Bourbon que chegara à corte portuguesa em 1789. A gestualidade entre a rainha e os príncipes do Brasil evidencia a união na partilha da ação de governo. À circularidade dos gestos da família real corresponde, do outro lado do quadro, o gesto do jovem que aponta às pessoas que o rodeiam o grupo real. Excetuando o rosto da criança, representado perto da moldura, nenhum dos retratados desse grupo olha para fora do quadro: ou olham entre si ou fixam o olhar na família real. O dedo indicador é colocado por cima da mulher de origens africanas, que tradicionalmente a crítica interpreta como sendo o contraponto à "figura tipicamente portuguesa ${ }^{69}$ que, à sua esquerda, olha para ela. À sua direita, a mulher em primeiro plano com um bebé ao colo olha também para a rainha. Cria-se deste modo um paralelismo entre a contemplação extasiada do Sagrado Coração por parte de Nossa Senhora e os olhares das duas mulheres dirigidos para a rainha D. Maria I. O grupo que contempla a família real está a rezar: duas crianças têm as mãos juntas, enquanto as mulheres seguram o terço nas mãos. Os olhares, os gestos de oração, a explícita indicação do jovem veiculam toda a atenção para a rainha, que se torna mediadora do amor de Cristo na terra.

Desta forma, enquanto na dimensão pública da basílica da Estrela, a tela de Batoni afirma a difusão universal do culto do Sagrado

${ }^{69}$ Moita (2005, p. 51). 
Coração nos territórios do império português, no espaço cortesão da capela real da Bemposta a pintura afirma a política da caridade inspirada no Sagrado Coração. No grupo dos reinantes, com efeito, não são retratados apenas os membros da família real, mas também as principais figuras de governo. Atrás dos reinantes, a posição de maior destaque é ocupada por Maria Francisca Benedita, irmã de D. Maria I e princesa-viúva do Brasil. Visível quase em meio corpo, ocupa o espaço lateral da pintura, denunciando a importância da sua posição na corte. Ao seu lado, é retratada a irmã Mariana. A seguir, ocupando uma posição atrás da rainha, reconhece-se o rosto do Intendente de polícia e diretor da Casa Pia Diogo Inácio Pina Manique (1733-1805). Ao pé dele, atrás e ao lado do príncipe D. João, distinguem-se outros rostos, entre os quais o de José Seabra da Silva e, provavelmente, de outros membros do governo a identificar.

Diogo Pina Manique foi uma figura-chave para a implementação das políticas de governo. Dirigiu a Casa Pia, fundada em 1780, que abrangia atividades no âmbito do ensino, da assistência e do desenvolvimento manufatureiro. A instituição atuava de acordo com a Intendência, ou seja o corpo de polícia recém-criado que visava diminuir a delinquência, a vadiagem e a prostituição que grassavam nas ruas da cidade de Lisboa. Pina Manique era também o comandante da polícia e a Casa Pia desempenhava funções de casa de correção, orfanotrófio, ensino básico e profissional. A paisagem pintada no fundo da tela da Bemposta representa o edifício da casa Pia, erguido ao pé do castelo de São Jorge de Lisboa. A sua presença interliga os dois grupos de retratos, identificando no da esquerda os beneficiados pela ampla ação da Casa Pia. A assistência às raparigas-mães, às raparigas sem dote e o resgate da prostituição, assim como o acolhimento de órfãos ou de crianças pobres é sintetizada nas características dos retratados à esquerda. Deste modo, a presença de uma mulher africana e a posição de destaque que ocupa ao centro do grupo das três mulheres vai além de uma 
nota exótica de costume como repete a historiografia. Enquadra-se na complexidade de um contexto social no qual a escravatura, os libertos e as consequências da abolição da escravatura apenas na metrópole marcavam profundamente a vida da cidade. ${ }^{70}$ Pela sua atitude é possível identificar a figura masculina que aponta o dedo como sendo um professor das várias classes de ensino previstas na Casa Pia. Ao seu lado, a criança que reza representa porventura a esperança no ensino especializado através do qual garantir uma vida melhor ou uma atividade no campo das artes. Na instituição dirigida por Pina Manique, juntamente com o ensino básico e manufatureiro foi incluído o ensino artístico. Alguns alunos frequentavam cursos de desenho, gravura, pintura, escultura, arquitetura e os melhores, desde 1785 , foram mandados para Roma a fim de se aperfeiçoarem. ${ }^{71}$ Na década de noventa, o ideal de juntar ensino, desenvolvimento das artes e progresso do reino foi sintetizado na Alegoria da Casa Pia pintada por Domingos Sequeira e no monumento em homenagem de D. Maria I, que Pina Manique encomendou aos "casapianos" que estudavam em Roma, para a nova praça diante da basílica da Estrela. ${ }^{72}$

Numa perspetiva estilística e compositiva, a pintura da Bemposta divide-se em três níveis, como a do altar-mor da basílica da Estrela, mas com uma significativa variação do plano intermédio, já descrita.

70 MENDES, A. de Almeida (2016), Esclavage et race au Portugal: une expérience de longue durée, em M. Cottias, H. Mattos (éds), Esclavage et subjectivité, Open Edition Press, Marseille http://books.openedition.org/oep/1495 consultado em 29 de julho de 2017.

71 Degortes (2016).

72 Vale a pena lembrar que o pedestal da estátua, executada pelo aluno da Academia Portuguesa em Roma João José Aguiar, apresenta um baixo-relevo que celebra as obras de D. Maria I (e de Pina Manique): os alunos casapianos, juntamente com Pina Manique, debruçam-se em direção da rainha. No fundo vê-se o castelo de S. Jorge, sede da Casa Pia: exatamente o mesmo cenário que Trono propõe na tela da Bemposta. Atualmente o monumento encontra-se em Queluz. Sobre este assunto veja-se DEGORTES M. (2018), "Mecenato e autocelebração de Diogo Inácio Pinamanique nos anos noventa de setecentos: o monumento de D. Maria I. Novos documentos» in Artis On, 7/2018, pp. 6-19. 
O Sagrado Coração domina a inteira composição. A sua luz dourada atinge diretamente Nossa Senhora, em contemplação no plano celeste, e desce sobre os membros da família real, que são retratados banhados por uma luz homogénea. Os extraordinários jogos de luz rasante, que atingem o grupo da esquerda, sublinham a presença da sombra. A família real e o grupo de governo servem de espelho refrativo para a luz que o Sagrado Coração emana. A diversidade simbólica da gradação da luz reflete-se na diversidade de efeitos estilísticos. Giuseppe Trono exibe a sua habilidade na pintura dos panos, transmitindo a consistência táctil dos tecidos e das cores através de lâminas de luz que sublinham, em particular, o branco dos lenços e as sombras projetadas no grupo da esquerda. Em relação ao vestuário da família real, o pintor piemontês atinge o ápice da sua habilidade. A rainha veste o traje requintado e bordado de todos os retratos que Trono pintou, assim como Carlota Joaquina apresenta um vestido semelhante ao da pintura do Prado, com tintas mais leves.

A relação com a Casa Pia é confirmada também pelo facto de a tela de Giuseppe Trono ter feito escola entre os alunos, em cujos quadros se encontram figuras inspiradas no modelo da Bemposta..$^{73}$ Ao longo do tempo a representação do grupo popular integrou até as gravuras aguareladas destinadas à venda comercial. O artista francês Zacharias Doumet, por exemplo, inseriu três mulheres para representar uma artificial 'cena de costume' relacionada com os costumes religiosos portugueses, dando à aguarela o título de "Attitude des Portugaises à l'église". ${ }^{74}$ [Fig. 8]

Pelas considerações até aqui apresentadas, a pintura da Bemposta pode ser atribuída totalmente a Giuseppe Trono como conceção

73 FERRAZ M., RODRIGUES J., SARAIVA L. (a cura di) (1990) Anástacio da Cunha 1744-1787, o matemático e o poeta, Imp. Nac. Casa da Moeda, Lisboa.

${ }^{74}$ Museu da Cidade, inv MC.PIN.0299. 
geral e execução, ultrapassando definitivamente a anterior afirmação crítica da presença de três pintores diferentes. ${ }^{75}$

Em conclusão, esta tela representa outra face da mesma moeda que, ao visualizar a missão político-religiosa da monarquia portuguesa, representa-a em versão pública, que se afirma universalmente na basílica da Estrela, e em versão privada, que se afirma pessoalmente graças aos retratos, na capela régia da Bemposta, de tal forma que tem o título de Consagração da monarquia portuguesa e do seu governo ao Sagrado Coração de Jesus.

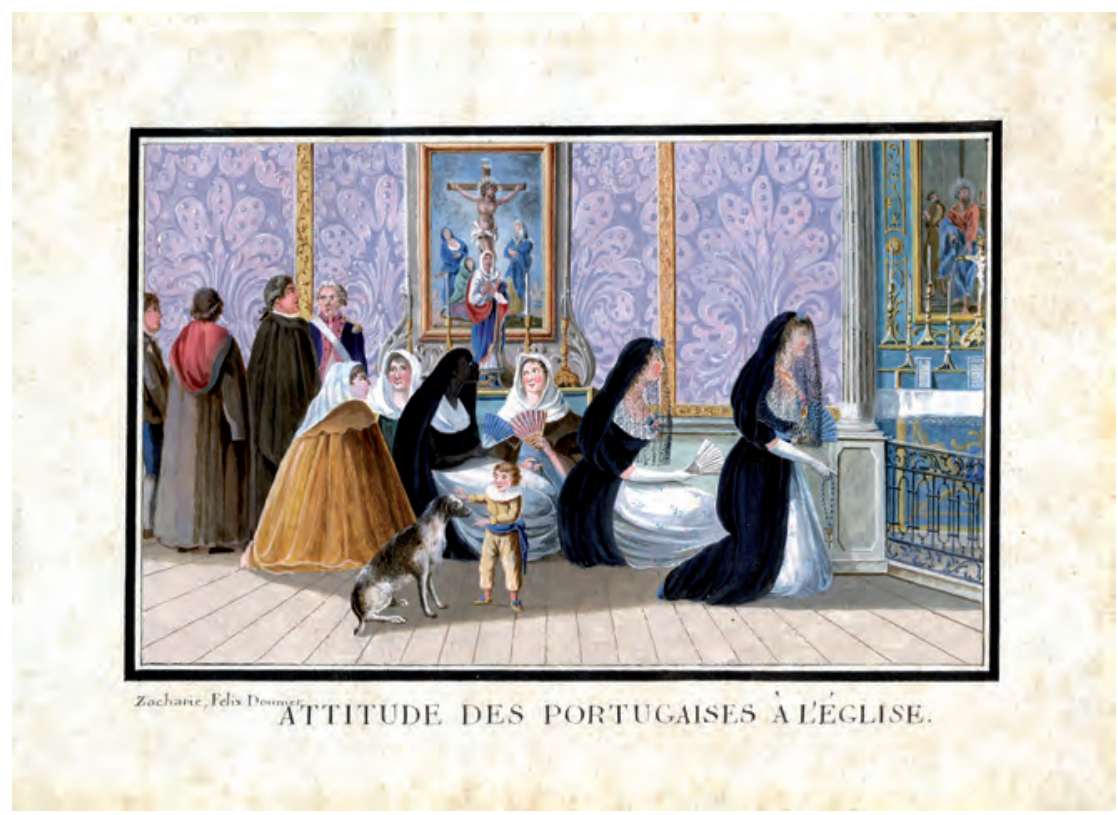

Figura 8 - Zacharie Felix Doumet, Attitude des portugaises à l'église, Lisboa, Museu da Cidade, MC.PIN.0299

75 Moita (2005, pp. 50-51) que atribuia a Hickey o grupo à direita, a Trono o da esquerda e a um terceiro pintor menos interessante o grupo ao alto. 


\section{Giuseppe Trono e a sociedade portuguesa do fim do século XVIII: retratos, miniaturas e mercado de objetos de arte}

Para descrever a relação de Giuseppe Trono com a realidade sociocultural lisboeta é preciso investigar a sua produção pictórica fora da corte e embora, até à data, tenham sido identificadas apenas quatro pinturas e uma gravura que retratam personagens pertencentes à elite lisboeta, é fácil supor que existam muitas outras, dispersas em coleções particulares.

A atividade de Trono no âmbito do meio da Arcádia Lusitana é confirmada por uma pintura que se conhece através de uma gravura: o retrato do árcade Myrtilo, ou seja Luis Rafael Soyé (1760-1831), autor das Noites Josephinas. Na gravura, a efígie de Soyé, representado em três quartos com uma lira na mão, é inserida num oval pousado num pedestal, e é acompanhada por um conjunto de elementos iconográficos - coroas de louro e de videiras, instrumentos musicais, livros, desenhos, uma máscara, dois putti, uma cornamusa - que celebram o interesse do autor pelas artes, a música, o teatro; uma composição alegórica concebida por Jerónimo de Barros e gravada por Gaspar Fróis Machado, que contém a indicação «Troni ef. pinxit Jer. Barros inv. G. Frois sc. Lx", confirmando que na sua origem há um retrato de Trono, do qual se desconhece a atual localização.

A gravura encontra-se na já mencionada obra Noites Josephinas de Myrtilo sobre a infausta morte do serenissimo senhor D. Joze, 76 que contém outra importante referência à obra de Trono. A efígie do príncipe D. José reproduzida na folha de rosto, também ela inserida num oval pousado num pedestal, é retomada do retrato em meio-busto que Trono pintou e do qual, como vimos, existem pelo menos três cópias (Runa, Queluz, Évora). Apesar de algumas alterações,

76 BNP L. 3637 P. http://purl.pt/13857 consultado em 20 de maio de 2017. 
por exemplo na forma de representar a Cruz de Cristo, a origem é evidente embora não seja especificada com a legenda Trono Pinxit.

$\mathrm{Na}$ Biblioteca Nacional encontra-se outra pintura [figura 9] realizada neste contexto e que não levanta dúvidas acerca da autoria: a personalidade representada, o retrato é em meio-busto, segura na mão direita um papel com a assinatura de Giuseppe Trono ${ }^{77}$. A pintura é muito bem conseguida pela forma eficaz como reproduz a expressão do rosto, a vivacidade do olhar e do encarnado que demonstram a habilidade de Trono em caracterizar psicologicamente o retratado, sobretudo em contextos menos formais, nos quais o pintor consegue captar a sua espontaneidade; em contraste com o fundo escuro, o efeito da luz rasante que modela o colarinho branco e a transparência das rendas são tratados cuidadosamente, embora a tela apresente umas patinas opacas e uns indícios de retoques que talvez tenham achatado o panejamento do casaco. O retratado é provavelmente o árcade e autor de peças de teatro Manuel de Figueiredo (1725-1801), ${ }^{78}$ membro da Arcádia Lusitana com o nome de Lycidas Cynhtio.

No Museu de Artes Decorativas de Lisboa encontra-se o suposto retrato de Catarina Naudin Arriaga ${ }^{79}$, [figura 10] surpreendida na intimidade da vida familiar juntamente com a filha; o registo formal, evidente na elegância do traje e do penteado embelezado com flores, pintados com a delicadeza das melhores obras de Trono, é atenuado pela atmosfera de ternura que impregna o quadro. A menina apoia-se na mãe, assomando com um olhar curioso numa

77 BNP, Inv. 10944. O cotejo da assinatura na tela com as assinaturas do contrato estipulado com a corte e do recibo para as despesas de viagem não deixa dúvidas acerca da sua autenticidade.

${ }^{78}$ Recentemente a identidade do retratado foi questionada, veja-se RODRIGUES, R. Massano, SOARES, C. Moura (2014), Manuel de Figueiredo ou o $2 .^{\circ}$ marquês de Vagos Controvérsias de identidade num retrato pintado por Giuseppe Troni pertencente à Biblioteca Nacional, in "ARTIS", 2, p. 196.

79 FRESS, Inv. 293. 
atitude levemente incerta, tipicamente infantil, tranquilizada pelo abraço materno; o simples vestido branco, o cabelo curto preso com um laço, o leve toque das mãos no braço da mãe, constituem um elemento de vivacidade em contraste com a pose vagamente austera da Arriaga que se vira, absorta e solene, para o espectador. Do ponto de vista cromático, o retrato pode ser comparado com o de Francisca Benedicta, no Museu dos Coches, onde encontramos o mesmo matiz de azul no vestido, e uma iconografia que privilegia a representação naturalista das grinaldas de flores, que neste último quadro todavia foram retocadas, em detrimento da habilidade de Trono na pintura dos elementos florais.

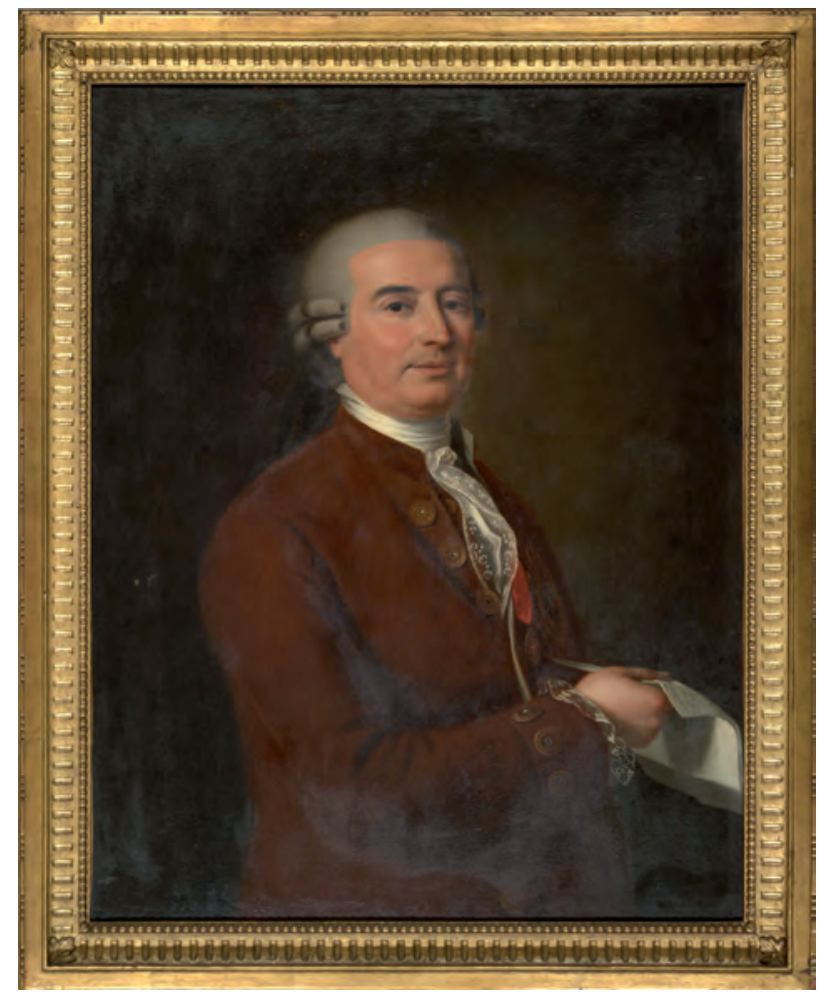

Figura 9 - Giuseppe Trono, retrato de Manuel de Figueiredo, Lisboa, Biblioteca Nacional de Portugal (C) BNP 10944 


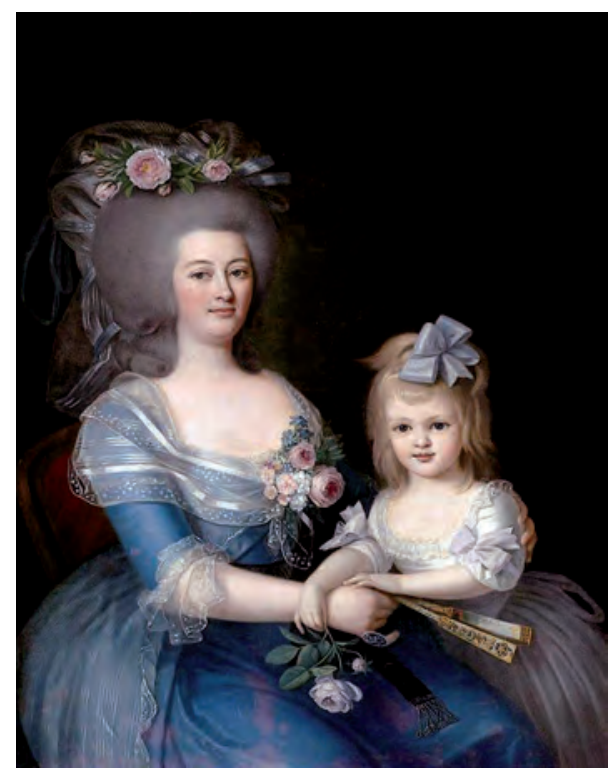

Figura 10 - Giuseppe Trono, retrato de Catarina Naudin Arriaga (?), Lisboa, Museu de Artes Decorativas Portuguesas, http://commons.wikimedia.org

Os retratos do cônsul sueco Martin Gierk ${ }^{80}$ e de António Araújo de Azevedo ${ }^{81}$, futuro conde da Barca, atestam as importantes relações que Trono estabeleceu no meio diplomático. Ambos os retratados apresentam uma pose semelhante: sentados a uma mesa na qual estão pousados uns papéis.

António Araújo de Azevedo (1754 -1817), personalidade política em ascensão durante os últimos vinte anos do século XVIII, foi um erudito, membro da Academia das Ciências, cujos interesses iam da arte à botânica, da química à tipografia. No retrato, apoia-se em dois livros e aproxima a mão do rosto, com expressão pensativa e introspetiva; a habilidade de Trono na pintura dos tecidos revela-se

${ }^{80}$ FRESS, Inv.926. A pintura sofreu restauros que alteraram a paleta cromática.

81 MNAA, Inv. 1710. Atualmente a pintura encontra-se na Embaixada portuguesa de São Paulo. 
neste quadro, onde ressaltam a renda do lenço, o bordado polícromo na camisa branca, os efeitos de claro-escuro no panejamento do casaco azul. Os traços fisiognómicos revelam uma idade à volta dos trinta anos e o retrato pode ser datado de antes de 1789, ano em que Azevedo, lançado na carreira política e diplomática, foi nomeado ministro plenipotenciário em Haia.

Em 1803 o pintor véneto Domenico Pellegrini (1759-1840) retratou o conde da Barca na mesma pose, sentado à mesa com o braço pousado nuns livros. Pellegrini chegou a Lisboa em 1802 e alcançou um enorme êxito, tornado-se o afortunado intérprete das exigências de uma classe social cada vez mais desejosa de se celebrar através do retrato, uma elite que não se limita ao meio aristocrático, mas abrange as personalidades mais influentes de abastados comerciantes. ${ }^{82}$ Em 1805 Pellegrini pintou também o grande retrato do príncipe regente, o futuro D. João VI, que se fez retratar também por Domingos Sequeira, mostrando a preferência pelas novas tendências do gosto que contribuíam para renovar o panorama artístico português. Nos primórdios do século XIX uma nova geração de pintores atraía o interesse da família real, com a qual já não conseguia competir, por novidade e frescura, a linguagem 'renovada', dez anos antes, do já mencionado retrato de Trono de Carlota Joaquina na Academia das Ciências. O contexto artístico português estava a mudar: em 1798 regressaram de Itália os artistas que se formaram na Academia Portuguesa de Belas-Artes em Roma e as figuras dominantes de Domingos Sequeira (1768-1837) e de Francisco Vieira Portuense (1765-1805) 83 ambos nomeados primeiros

82 Sobre a obra de Pellegrini em Lisboa veja-se PAVANELLO, G. (2013), Domenico Pellegrini 1759-1840 Un pittore veneto nelle capitali d'Europa, Scripta Edizioni, Verona.

83 Francisco Vieira Portuense, pintor cosmopolita que se formou em Roma e em Parma, regressou a Portugal em 1800, depois de uma viagem por Itália, Alemanha, Áustria e Inglaterra. Domingos Sequeira, que em Roma fora nomeado Académico de São Lucas, regressara a Lisboa em 1796. 
pintores da corte, afirmaram-se no cenário artístico contemporâneo. Portugal, como toda a Europa, atravessava uma época de profundas mudanças políticas e sociais, marcada pelas invasões napoleónicas e pela partida da corte para o Brasil, que aconteceu em novembro de 1807.

Neste contexto perde-se o rasto de Giuseppe Trono. Com efeito, a sua última obra que pode ser datada com segurança é o painel do altar da Bemposta, pintado entre 1792 e 1793. Todos os retratos idenficados no presente estudo são anteriores ao ano de 1793, excetuando o de Carlota Joaquina, conservado na Academia das Ciências, que não ultrapassa o ano de 1795. Sendo assim, embora se mantenha a hipótese da existência de outras obras ainda desconhecidas, a atividade do pintor piemontês como retratista concentra-se na primeira década da sua estadia em Lisboa, ou seja durante o reinado de D. Maria I. O que terá acontecido, então, entre 1795 e 1810, isto é durante os seus últimos quinze anos de vida?

É provável que a partir de dada altura, Giuseppe Trono aproveitasse a sua habilidade como miniaturista para ampliar a sua atividade nesse âmbito. A rede de contactos estabelecida nos anos em que trabalhara para a família real assegurou-lhe ótimas relações com a alta sociedade lisboeta. As miniaturas podiam ser mais ou menos valiosas conforme os materiais utilizados como suporte, alimentando um comércio de objetos artísticos não limitado aos meios sociais mais restritos, mas transversal a diferentes tipologias de clientes. Tendo em conta que Volkmar Machado, na sua breve nota acerca de outro pintor piemontês, Bernardino Gagliardini (Vocca, 1757 - Lisboa 1833), ${ }^{84}$ define-o Throno pequeno, e é muito provável

${ }^{84}$ Segundo Machado (1823), Gagliardini chegou a Portugal juntamente com Trono em 1785, una hipótese a verificar dado que nenhuma das pormenorizadas cartas do cônsul em Génova Piaggio fala disso. Sobre a relação entre Trono e Gagliardini veja-se BASTOS C., DEGORTES M., RAGGI G. (2018), "Giuseppe Antonio Trono e Bernardino Gagliardini, pintores de retratos no reinado de D. Maria I. Novos dados de investigação" in Artis On, 7/2018, pp. 202-212. 
que Gagliardini se dedicasse sobretudo às miniaturas a partir da produção pictórica de Giuseppe Trono, podemos supor que Trono tivesse organizado à sua volta uma oficina especializada nesse âmbito, com a ajuda também dos alunos que se formaram com ele na pintura de retratos. Outra atividade de Giuseppe Trono que deve ser investigada tem a ver com o mercado de objetos de arte, isto é o comércio de desenhos e cópias de pinturas famosas que ele próprio realizara. Sabe-se que quando chegou a Lisboa trazia várias cópias de pinturas de grandes mestres italianos e que com estas cópias se tinham exercitado quer os seus alunos, quer alguns expoentes da alta sociedade que se dedicavam ao estudo da pintura como foi o caso da já mencionada mulher do embaixador holandês, amigo íntimo de Trono. Nesse meio de colecionadores e amantes das belas artes, o comércio de cópias dos mestres italianos teve uma boa saída. A confirmar o êxito no mercado de objetos de arte está o facto de, entre os seus bens leiloados após a sua morte, figurarem obras e cópias de vários autores, objetos valiosos e miniaturas.

Por fim, no museu Soares dos Reis do Porto, existe um retrato que representa um jovem, identificado num catálogo do século XIX como sendo um autorretrato de Giuseppe Trono ${ }^{85}$. Uma identificação sem dúvida sedutora mas que precisa de uma mais aprofundada investigação, dado que o retratado não exibe nenhum elemento associável ao ofício de pintor, o que destoa com a perícia de um retratista como Trono, sempre muito atento em colocar objetos de clara referência simbólica para identificar o papel e o estatuto dos seus retratados ${ }^{86}$.

A descrição deste primeiro catálogo das obras de Giuseppe Trono, levada a cabo neste ensaio, atesta a sua abuntante produção. Há

85 SANTOS (1999).

86 Numa coleção particular existe outro suposto autorretrato, atualmente objeto de estudo. Veja-se RAGGI G., DEGORTES M. (2018B). 
ainda muito por descobrir, mas um dado certo é que, quando as tropas de Napoleão entraram em Portugal e o príncipe regente decidiu partir para o Brasil, em novembro de 1807, o pintor piemontês não fez parte da grande comitiva. Em 1808, com 69 anos, tomou a decisão de fazer a viagem em direção contrária, tentando alcançar a cidade de Turim. A guerra deteve-o em Espanha, obrigando-o a regressar a Portugal. Em 1810 faleceu na terra onde vivera os seus últimos 25 anos de vida e que, apesar das parcas notícias, manteve viva a sua memória. Com efeito, deve-se ao escrito de Cyrilo Volkmar Machado o conhecimento da sua biografia artística. As indicações relativas à sua atividade em Itália constituem pistas valiosas para que se comece a descrever a sua história artística e pessoal também em Turim, Roma e Nápoles. A experiência feita ao longo dos vinte anos de viagem pela Itália desempenhou um papel fundamental para a sua contratação junto da corte portuguesa, para as obras que produziu em Portugal, e para o conhecimento artístico que difundiu neste país e o legado cultural que deixou. 


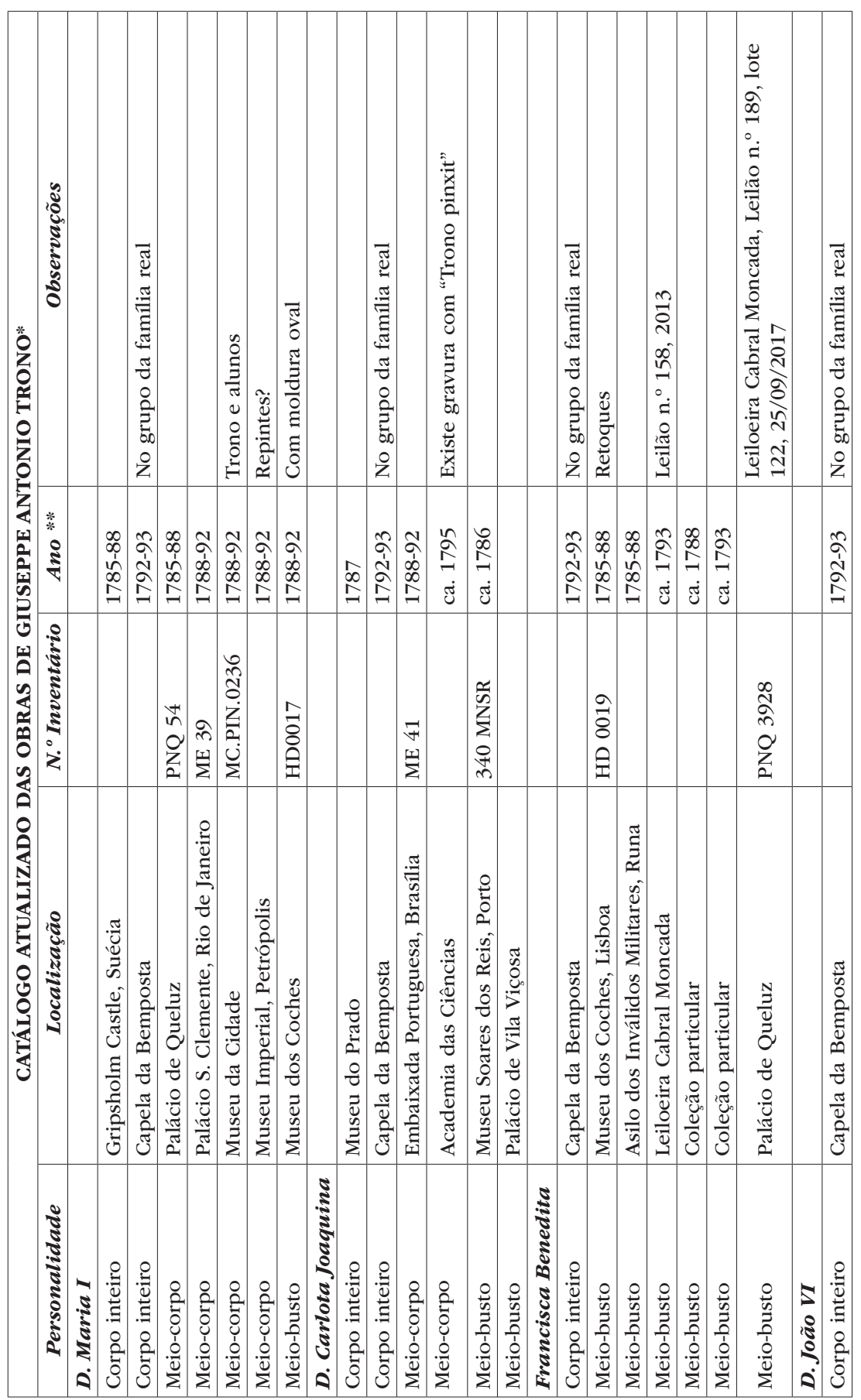




\begin{tabular}{|c|c|c|c|c|c|c|c|c|c|c|c|}
\hline 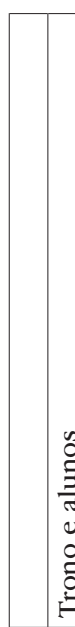 & $\mid \begin{array}{l}0 \\
0 \\
\vdots \\
0 \\
0 \\
0 \\
0 \\
0 \\
\end{array}$ & 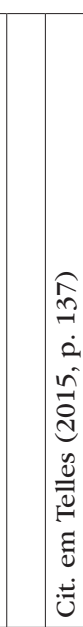 & & & & 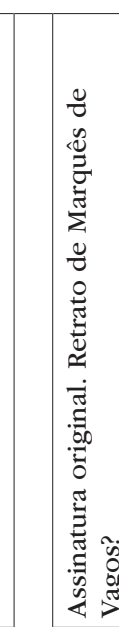 & & & 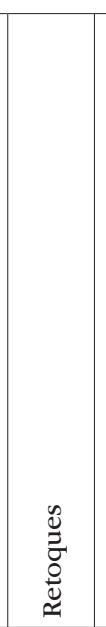 & 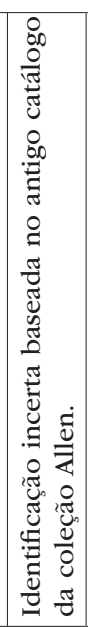 & 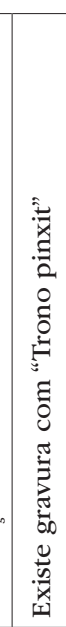 \\
\hline 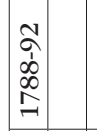 & & 竞 & 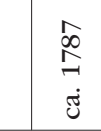 & 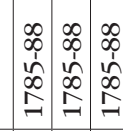 & 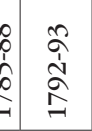 & & 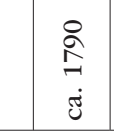 & & & & \\
\hline 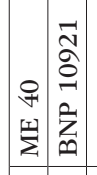 & 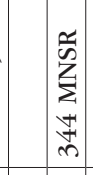 & & 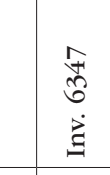 & 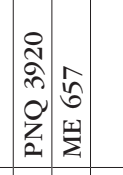 & & 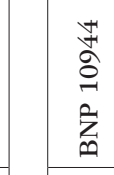 & 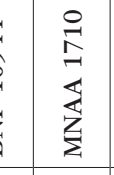 & 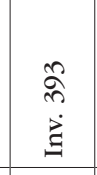 & $\begin{array}{l}\text { ふू } \\
\text { हे }\end{array}$ & 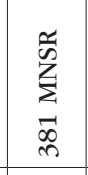 & \\
\hline 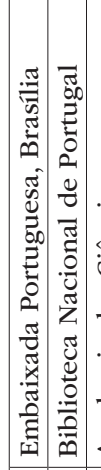 & 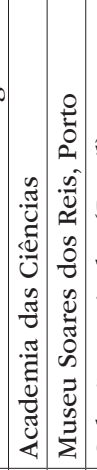 & 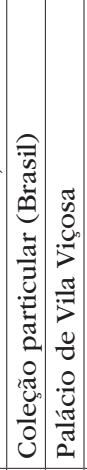 & 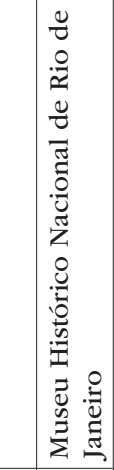 & 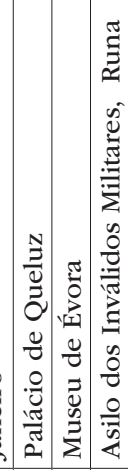 & 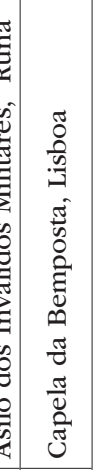 & 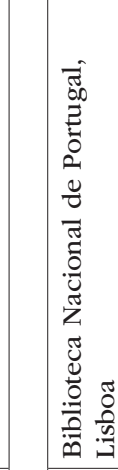 & 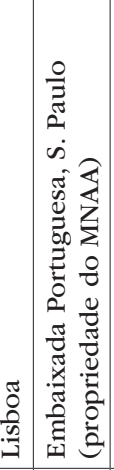 & 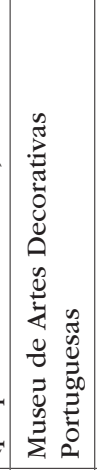 & 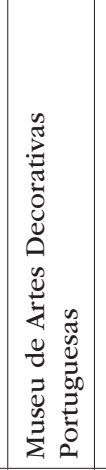 & 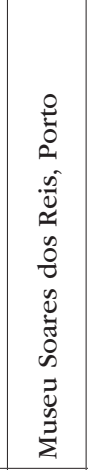 & 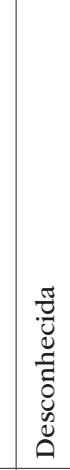 \\
\hline & & $\frac{\bar{d}}{\frac{\delta}{2}}$ & 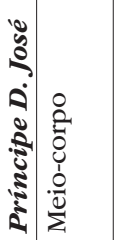 & 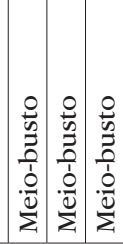 & 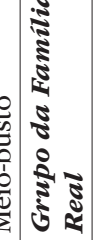 & 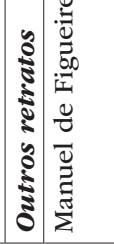 & 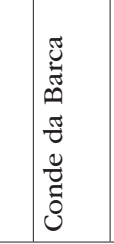 & 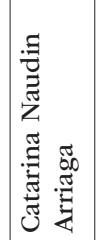 & 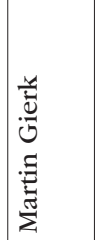 & 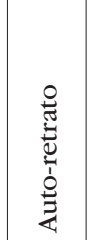 & 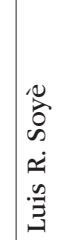 \\
\hline
\end{tabular}




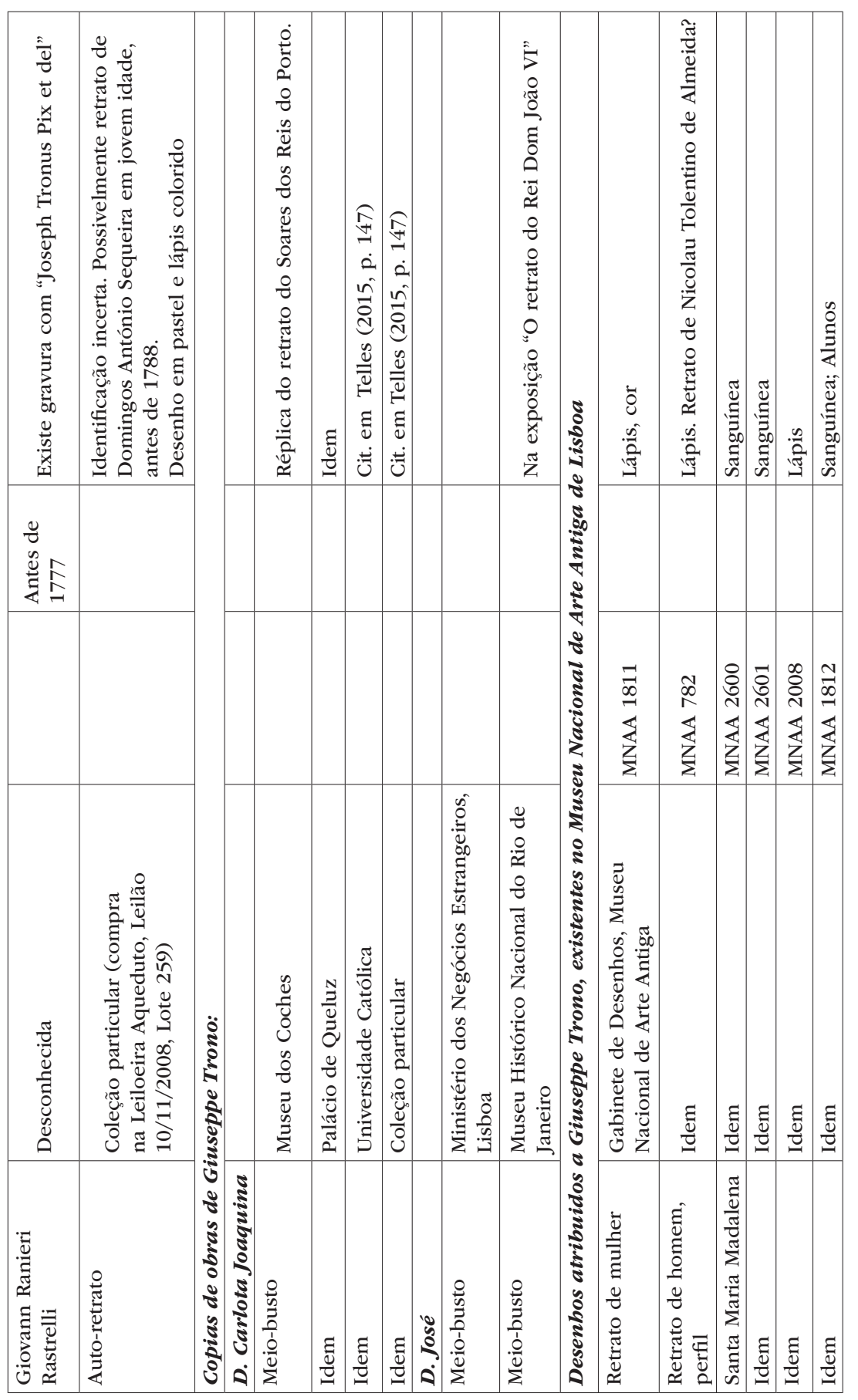




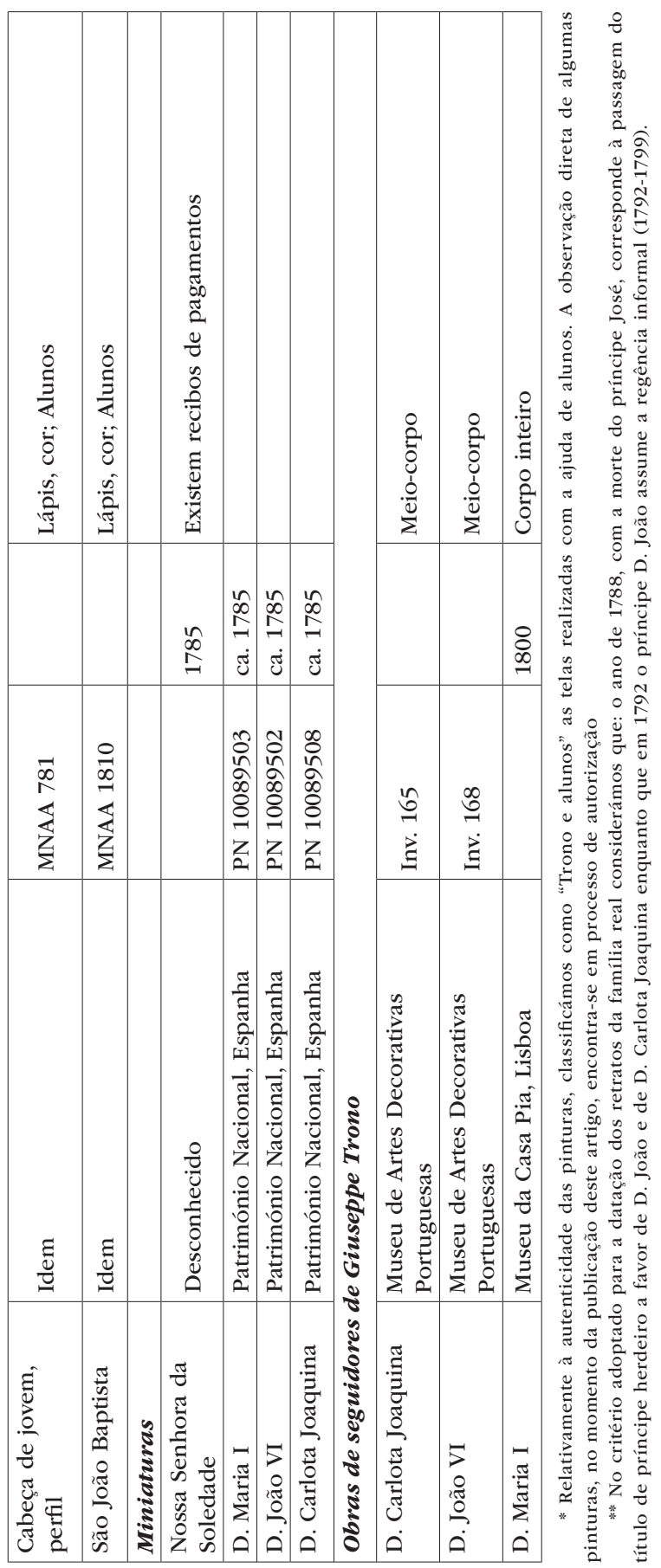

